\title{
La magia hindú y su proyección hacia occidente en el mundo antiguo
}

\author{
Mำ TeResa Román LóPez *
}

\section{RESUMEN}

La aproximación al hinduismo implica, entre otras cosas, ponerse en contacto con sus orígenes mágicos.

Las creencias mágicas prearias son difíciles de describir. No obstante, hallamos ritos védicos que son mágicos a pesar de que forman parte del ámbito del sacrificio.

El documento religioso más antiguo de la India es una colección de himnos, los Veda. Los himnos védicos nos muestran la forma más antigua de la religión védica.

Es escasa la información que poseemos sobre las creencias mágico-religiosas en la civilización del Valle del Indo, no hablan de: a) la persistente disposición a contemplar lo sagrado en función de la maternidad; b) el karma o ley de causa y efecto.

La religión védica consiste en una mitología muy elaborada. Los dioses estaban ligados con las fuerzas naturales e intervienen sin cesar en los asuntos humanos.

Uno de los métodos básicos del hinduismo es el yoga. Se supone que su práctica puede proporcionar, como efecto secundario, la adquisición de unos "poderes milagrosos".

De los tiempos védicos se ha conservado el concepto de potencia mágica del mantra o fórmula sagrada.

Un conocido diagrama místico es el mandala o círculo mágico.

\footnotetext{
* Departamento Filosofía Moral y Política. UNED.
} 


\section{SUMMARY}

The aproximation to hinduism involve among other things to have contact with its magic origins.

The pre-arian magic beliefs are difficult to describe. Althought we found vedies rites that are magic spite of they are part of the sacrifice ambit.

The ancient religious document of India is a hymn collection, the Veda. The Vedic hymns show as the most antique form of the vedic religion.

We have short information about the magic religious beliefs in the Valley of Indo civilization. This information doesn't talk about:

a) The persistent aptitude to contemplate the sacred things according to the motherhood.

b) The karma or cause and effect law.

The Veda religion consists on a very elaborated mitology.

The gods were tie the natural powers and they constantly mediate in the human matters.

One of the hinduism basic methods is the Yoga. It's suppose that its practice may proportion as a second effect, the acquisition of miraculous powers.

Of the vedic times has been conserved the concept of magic power of the Mantra or sacred formula. One known mistic diagram is the mandala or magic circle.

\section{EL MARCO HISTÓRICO}

\subsection{Las civilizaciones del Indo}

La India tiene una extensión de $3.268 .090 \mathrm{Km}^{2}$ y aproximadamente 700 millones de habitantes, que después de China, la colocan en la posición de ser el segundo país más poblado del globo.

El nombre de India deriva del río Indo, y éste, a su vez, fue dado por los griegos, tomándolo del vocablo sánscrito sindhu, que significa precisamente "río».

La mayor parte del territorio indio está más cercana al Ecuador que África del Norte. Además, las grandes barreras montañosas del Norte aislan al país entero, de manera que éste presenta la forma de dos triángulos de desigual tamaño, el menor situado encima del más extenso, el cual aparece invertido. 
El triángulo del Norte se encuentra dentro de la zona templada, mientras que el del Sur cae dentro de los Trópicos. De las montañas norteñas fluyen grandes ríos, y no llama la atención el hecho de que los habitantes de las bien regadas llanuras contemplaran con religioso temor el grandioso Himalaya, centro del mundo; y consideraran sagrada la caudalosa corriente del Ganges, uno de los cuatro ríos que nacen en el mítico monte Kailas, al que atribuyen un origen divino.

Entre el Himalaya y el Vindhya, o "divisoria»-una cordillera árida y rocosa que separa uno del otro los dos triángulos-, se extiende un vasta llanura. En ella vive la mitad de la población india.

La península del Sur tiene la mayor parte de la población concentrada en las zonas costeras.

La India es cuna de tipos antropológicos muy diversos, a los que se sumaron numerosos invasores.

La prehistoria de la India no ha sido aún investigada en profundidad, pero la presencia de instrumentos líticos y de pinturas rupestres parece sugerir la presencia en una época lejana e indeterminada, de grupos humanos de un nivel cultural equivalente a los denominados «auriñacienses»'.

Según Trevor Ling:

"Con anterioridad a la llegada de los nórdicos, el subcontinente indio fue escenario de una mezcla considerable de tipos étnicos, de los cuales el negrito es quizá conocido con mayor prioridad, seguido por las razas australoides, mediterráneas y mongólicas. Los pueblos australoides están representados por pequeñas concentraciones de tribus mundahablantes. El elemento mediterráneo corresponde a los grupos de habla drávida de la India meridional. Los mongoles abundan en el área septentrional, a lo largo de las colinas que bordean el Himalaya" ${ }^{2}$.

Lo cierto es que el hombre primitivo penetró en la India en una época remota, y es muy probable que se extendiera hacia el Este a través de lo que actualmente denominamos Indonesia, llegando asi hasta las islas del Pacífico.

En 1921, en el curso de las excavaciones dirigidas por Daya Ram Sahni, en Harappa (Punjab) y Rakhal Das Banerji, en Mohenjo-Daro (Sindh), reveladas por sir John Marshall en tres volúmenes publicados en

1 Ver E.O. JAMEs (dir.), Historia de las religiones, Vergara, Barcelona, 1963, Vol. I, p. 232. AA.VV., La India Antigua y su civilización, Uteha, México, 1957, pp. 15-18.

2 T. LING, Las grandes religiones de Oriente y Occidente, Itsmo, Madrid, 1972, p. 64. 
1931, aparecieron los restos de una antigua civilización de la Edad del Bronce. Desde entonces, las sucesivas excavaciones han permitido desenterrar una importante serie de yacimientos y reunir una abundante documentación sobre la civilización del Indo denominada también de Harappa, de Mohenjo-Daro o incluso civilización prevédica.

Mohenjo-Daro ${ }^{3}$, la capital, fue una ciudad próspera de $5 \mathrm{kms}$. de contorno, aireada y urbanizada, con establecimientos de baños, edificios altos y un sistema de cloacas subterráneas. Edificada hacia el 2500 a. de C., Harappa era la segunda ciudad más importante del país. En ella se descubrió una necrópolis con los esqueletos orientados de norte a sur, con la cabeza hacia el norte. Su escritura aún no ha podido ser descifrazada. Hacia el 1500 a. de C., las invasiones arias pusieron término a esta civilización.

Posteriormente se han encontrado vestigios de la misma civilización en lugares tan distantes como Kathiawar en el Oeste y en el distrito de Ambala, en el Punjab, y hay motivos para creer que se extendía también hasta el valle del Ganges. No se trataba, pues, de la "civilización del valle del Indo", sino de una una cultura muy difundida por vastas áreas de la India, especialmente en el Norte. Al parecer se trataba de una civilización muy evolucionada, que debió tardar muchos siglos en llegar al esplendor indicado por estos descubrimientos arqueológicos ${ }^{4}$.

El pueblo que dió origen a esta civilización pudo estar emparentado con los primeros sumerios asentados en Mesopotamia; es probable que ambos pueblos fuesen ramas de un tronco común, quizá originario de las regiones que circundan el actual Beluchistán; también es posible que, en una época situada en el 4000 a. de $C$., estos pueblos penetraran en la India, y se establecieran alli. Probablemente se mezclaron los aborígenes, los negritos y los australoides, de modo que la civilización y la raza que de ellos resultó contenía una fusión de elementos pertenecientes por igual a conquistadores y conquistados. Este pueblo colonizador es comúnmente conocido con el nombre de "drávida», y a los primeros invasores podemos llamarles "protodrávidas" 5 .

Nuestros conocimientos sobre la religión de aquellas gentes derivan casi por completo del gran número de amuletos o sellos finamente labrados, a falta de toda construcción que pueda identificarse con cierta segu-

3 La fecha de Mohenjo-Daro viene sugerida por un sello procedente del valle del Indo aparecido en Tell-Asmar, en Mesopotamia, en un estrato fechado hacia el 2500 a. de C., aunque los comienzos de esta civilización probablemente son mucho más antiguos.

4 Ver E.O. JAMEs (dir) ob. cit., p. 336.

5 Ibid., ibíd. 
ridad como un santuario o templo. Además de los baños utilizados para las purificaciones rituales, innumerables estatuillas de cerámica parecen tener un significado mágico-religioso y quizá aportan el testimonio de un culto de la fecundidad (Figura 1) paralelo al relacionado con la Diosa-Madre en otras religiones del antiguo Oriente.

Una figura con cabeza y busto, ejecutada en esteatita, con barba y vestida con túnica que la ciñe sobre el hombro izquierdo y bajo el derecho, ornada con una cenefa de tréboles que aparecen con frecuencia con valor de símbolos sagrados, guarda cierto parecido con imágenes divinas sumerias ${ }^{6}$. Ésta representa posiblemente una deidad masculina, y se ha dicho que los ojos entornados y dirigiendo la mirada hacia la punta de la nariz, podrian indicar un estado de meditación o de contemplación, tan común en las estatuas hindúes (Figura 2).

Muchas tablillas de barro muestran probablemente deidades masculinas con cuernos, en tanto que en un sello aparece una figura femenina con cuernos, de pie, con un recargado peinado, casi desnuda, si exceptuamos un cinto y un collar, es quizá una diosa y podría ser identificada como la Diosa-Madre o la Diosa-Tierra ${ }^{7}$; aparece entre dos ramas de

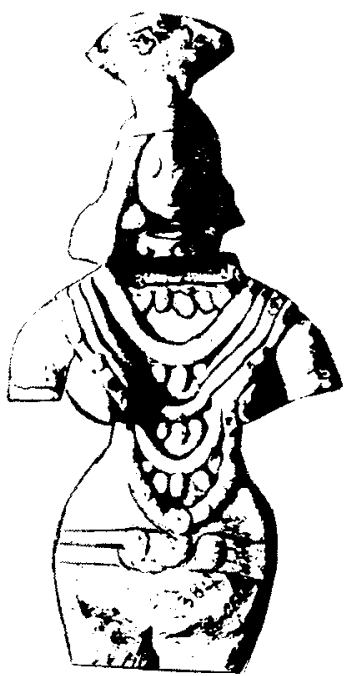

Figura 1. Diosa del Indo, estatuilla de Mohenjo-Daro (Museo Guimet).

6 Ver E.O. JAMES, Introducción a la Historia Comparada de las Religiones, Cristiandad, Madrid, 1973, p. 155.

7 Ver M. ElIADE, Yoga, inmortalidad y libertad, La Pléyade, Buenos Aires, 1988, p. 336. 


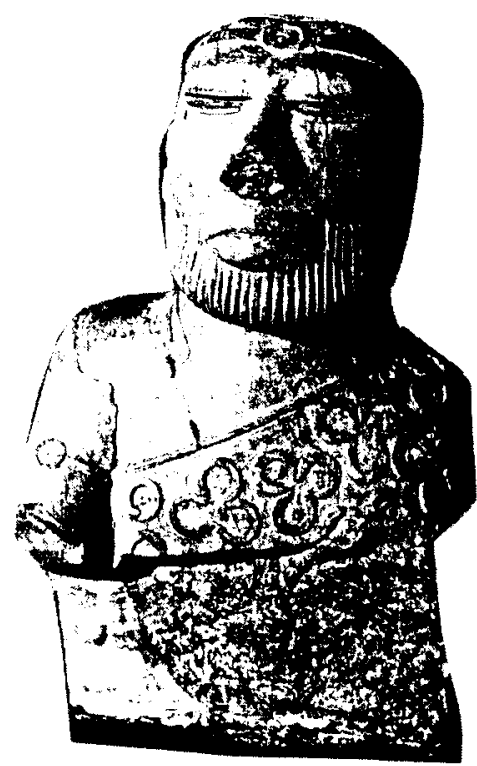

Figura 2. Encontrado en Mohenjo-daro, en el valle del Indo, este busto masculino de esteatita procede de 2000 a 1750 a.C.

pipal, la higuera sagrada de la India. Ante ella, otra posible divinidad con cuernos, arrodillada,seguida por un búfalo, hace un gesto de súplica y siete jóvenes con diademas y largas cabelleras. La asociación mujer-pipal es muy frecuente en los sellos prevédicos. Hay que sumar a ésta la frecuencia de estatuillas femeninas. Nos encontramos con un culto a la fertilidad-fecundidad en el contexto de una civilización matriarcal. Es probable que en la evolución posterior del hinduismo, la corriente de la bhakti ${ }^{8}$ y más tarde la doctrina de la sakti ${ }^{9}$ sugieren quizá cierta influencia del pensamiento religioso matriarcal prevédico, conservado en las tradiciones dravídicas.

B Lo que domina al hinduismo de un extremo a otro de su historia, es la "devoción" (bhakti), que le opone poderosamente al ritualismo védico. Esta forma religiosa cubrió la India de templos, movilizó muchedumbres de peregrinos de todas las castas y de todos los lugares que recorrían la India de norte a sur y de este a oeste, mientras que el acto esencial de la religión védica, el sacrificio, desaparecía casi totalmente de la práctica religiosa y conservaba sólo una importancia teórica.

9 Término sánscrito que, en el hinduismo expresa la idea de «poder", especialmente el de creación, de Dios. Es típico entenderlo como una entidad femenina. El culto de la sakti personificada es conocido con el nombre de saktismo (forma peculiar de shivaismo), y juega un papel muy importante en el tantrismo (una forma de ritualismo sacramental, unido a veces a ciertos rasgos esotéricos y mágicos, que caracterizan a ciertas formas del hinduismo y del budismo). 
En la India, donde la santidad de la vaca es un rasgo característico del hinduismo ortodoxo, éste era al parecer desconocido entre los arios cuando se compiló, entre 1500 y 1000 a. de C., el Rigveda, colección de himnos antiguos en honor de los dioses de la naturaleza. La primera prohibición de dar muerte a la vaca surge en el Atharvaveda, edición relativamente tardía de ritos o exorcismos y prácticas de magia. Con anterioridad se ofrecía a Indra y a otras deidades védicas cualquier clase de animales; la vaca fue eximida únicamente como concesión a una opinión posterior. Se podría decir, por tanto, que el origen de esta veneración habría de buscarse en una anterior cultura no aria, que estaba instalada en la India hacia el $3000 \mathrm{a}$. de C.

Escenas como las descritas y la gran cantidad de figuras femeninas, casi desnudas, con un ceñidor en la cintura, peinados muy recargados, brazaletes de oro y hasta collares, junto con los símbolos fálicos además de betilos y de anillos, el lingam o piedra cónica, así como el culto al toro y a la serpiente, "relacionan la civilización del valle del Indo con la de Creta y otras culturas semejantes» 10 .

Dado que en el mitología védica apenas se mencionan los espíritus de los árboles y el culto fálico no aparece, estos rasgos del hinduismo podrían ser originarios de la India prearia. En este sentido tiene sumo interés una figura con cuernos, y sentada en un trono a la manera india con tres rostros. Está rodeada de dos ciervos, un rinoceronte, un tigre, un búfalo y un elefante. El arqueólogo inglés sir John Marshall se arriesga a reconocer al propio Shiva, el dios popular de la India, señor del ganado y príncipe del yoga ${ }^{11}$. Así pues, estariamos ante las raíces del shivaismo ${ }^{12}$, que se inspiraria en el pensamiento religioso de Mohenjo-Daro.

El arte animalístico alcanza en Mohenjo-Daro una gran perfección con la representación del búfalo, el unicornio, el toro, el rinoceronte y el tigre. Algunos estudiosos han querido ver un culto a los animales asociado a los dioses. Esto podría explicar la conexión animal-dios que hallamos con frecuencia en el hinduismo, y que no obstante, está ausente en el pensa-

10 E.O. JAMES, ob.cit., p.156.

"El término "yoga" se utiliza de diversas maneras. La referencia más típica es a los métodos de dominio de si mismo y meditación, que en la tradición india adoptan diversas modalidades; asi se puede hablar de yoga hinduista, jainista, budista, etc. En sentido más estricto, el término se toma como designación de una de las seis escuelas ortodoxas de la filosofía hindú, con sus doctrinas y métodos. En un sentido mucho más amplio, con este vocablo se designa también todo método o disciplina encaminada a la salvación.

12 Una de las tres grandes orientaciones del culto divino en el hinduismo moderno. Los shivaítas consideran a Shiva como la divinidad suprema, creadora, destructora y conservadora del universo, y sólo a él rezan y rinden culto. 
miento arcaico del Veda ${ }^{13}$. La veneración hindú por determinados animales puede tener su génesis en las tradiciones del Indo. Los sellos y las distintas piezas de cerámica decorada con hojas de pipal hacen suponer a los investigadores que hubo un culto al árbol sagrado, unido al culto a la diosa.

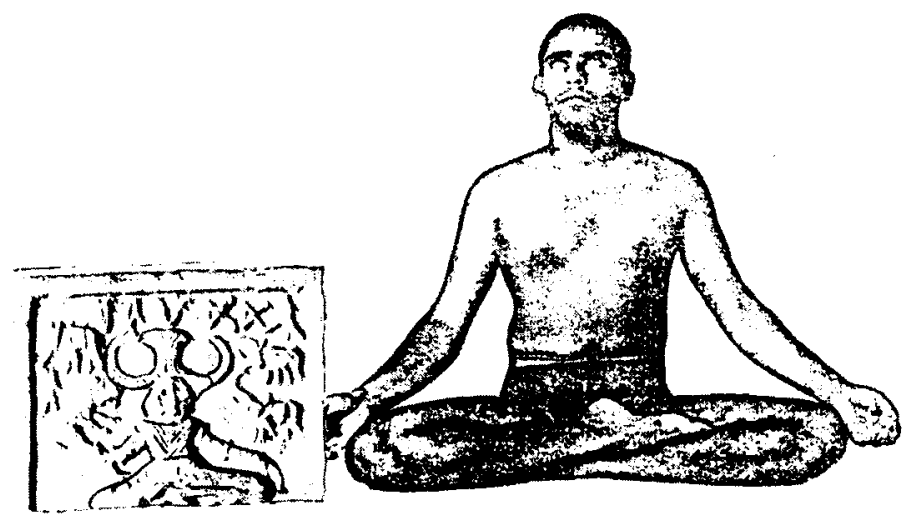

Figura 3. La práctica del yoga (derecha) puede remontarse a la civilización del Indo, como nos deja adivinar el personaje de piernas cruzadas (recuadro) de Mohenjo-daro. Algunos eruditos han especulado con la idea de que el yogui del sello es un precursor del posterior dios Shiva en su aspecto de "Señor de los animales".

\section{l.2. El tronco indoeuropeo y la rama aria}

Hasta aproximadamente el año 2000 a. de C. los pueblos semitas, principalmente en Egipto y Mesopotamia, habian protagonizado, casi en exclusiva, los movimientos de cultura y de civilización de la humanidad. Pero a partir de esta fecha unos pueblos bien definidos por su lengua y cultura, los indoeuropeos, entraron decidamente en el concierto de la historia universal. Desde entonces su influencia, poder y participación histórica, irá creciendo hasta convertirse durante muchos siglos en centro y motor de la civilización y el progreso: indoarios, hiksos, hititas, persas, griegos, medos, serán los principales forjadores de reinos o imperios en la Antigüedad.

El desarrollo de la filología comparada en el siglo XIX condujo a la idea de que existió un grupo racial cuya lengua habría sido la fuente de otras varias que estaban emparentadas entre sí. En efecto, en 1783, William

13 Literalmente, "saber». Es la denominación dada al conjunto de los textos sagrados del hinduismo brahmánico. 
Jones se percató de las semejanzas entre el latín, el griego, el sánscrito, el alemán y el persa antiguos, postulando un antepasado común para todas esas lenguas: el indoeuropeo ${ }^{14}$.

Se denominan pues indoeuropeos a los primitivos hablantes del indoeuropeo. A partir del estudio del indoeuropeo y de los datos materiales de sus posteriores migraciones no ha sido difícil reconstruir de forma hipotética los aspectos más significativos de su cultura. Podemos situar la época de los primitivos indoeuropeos en los dos milenios entre el 4000 y el 2000 a. de C.

El país originario de los indoeuropeos no está determinado aún con seguridad, no obstante, se ajustan bien al área centroeuropea los vocablos culturales y los nombres de animales y de plantas de las diferentes lenguas indoeuropeas. Algunos investigadores señalan las estepas del sur de Rusia como país de origen.

Los indoeuropeos eran hombres de elevada estatura y de piel clara. Podemos entrever una sociedad de pastores (cerdos, bovinos, ovejas) y recolectores de miel que practicaban una agricultura de complemento. Tuvieron algún contacto con la cultura sumeria, de la que adoptaron el yugo, el carro y el hacha con mango ${ }^{15}$.

Mediante un estudio comparativo, iniciado sobre todo por Max Müller, de la mitología del Rigveda ${ }^{16}$, el Avesta ${ }^{17}$ y la literatura griega, se trató de reconstruir la primitiva religión de los indoeuropeos. Se afirmó que ésta estaba centrada en la figura de una deidad celeste Dyaus, afín a Zeus y Júpiter, o Agni, el dios del fuego. La tormenta, el rayo-fuego y el viento son otras tantas deidades importantes, que simbolizan la fuerza. Al parecer, los indoeuropeos no conocen imágenes de dioses ni templos. Los dioses acuden al que hace la ofrenda, al que está preparado para el sacrifico, una vez que ha delimitado el lugar del sacrificio y lo ha cubierto la hierba del sacrificio. Durante la ceremonia se exprime el soma (bebida sagrada) y se encienden los fuegos sagrados, se ofrendan manjares rituales y se sacrifican animales. Himnos que alaban a las divinidades invocadas acompañan estos actos.

Los sacrificos védicos eran un privilegio de la casta de los brahmanes, que se estaba forjando y que hizo del ritual del sacrificio una ciencia secreta, con un simbolismo repleto de referencias alegóricas, que sólo era y debía ser comprendida por unos pocos y que se transmitía oralmente a un

14 Ver J. Mosterín, El pensamiento de la India, Salvat, Barcelona, 1982, pp. 6-7.

15 Ibid., p. 8.

16 Es una colección de himnos en honor de los dioses compuesta por los sacerdotes indoarios aproximadamente entre el 1500 y el 900 a. de $\mathrm{C}$.

17 Nombre de los escritos sagrados de los antiguos persas atribuidos a Zoroastro. 
reducido número de discípulos, escogidos después de pruebas rigurosas. El favor de los dioses no era lo más importante; era el mismo rito del sacrificio celebrado correctamente lo que producía el efecto deseado. La religión védica se fue transformando a medida que lo hacía la sociedad védica.

Comparando sistemáticamente la estructura social y las creencias religiosas de los pueblos de origen indoeuropeo, Georges Dumézil ${ }^{18}$ ha conseguido reconstruir un rasgo básico de la sociedad y de la religión indoeuropeas: a la división de la sociedad en tres clases - sacerdotes, guerreros y ganaderos-agricultores - correspondía una ideología religiosa trifuncional: la función de la soberania mágica y jurídica, la función de los dioses de la fuerza guerrera y, por último, la de las deidades de la fecundidad y de la prosperidad económica. En efecto, en la India antigua, a las clases sociales de los vaisyas (agricultores y artesanos), ksatriyas (militares) y brahmanes (sacerdotes), corresponden las divinidades Indra, los gemelos Nasatya, Mitra y Varuna; los celtas clasificaban la sociedad en druidas (sacerdotes), flaith (aristocracia militar) y bo airing (poseedores de vacas). $Y$ las mismas clases se observan entre sus divinidades. El que los pueblos de origen indoeuropeo, como los indoarios y los celtas, pero situados a grandes distancias y sin contacto posible, presenten tales similitudes en su religión, parece dar cierta consistencia a la reconstrucción de Dumézil, a pesar de su carácter hipotético.

En resumen, todo lo que podemos señalar sobre los indoeuropeos es una mera hipótesis. Lo único que se sabe con certeza es que irrumpen hacia el año 2000 a. de C. con fuerza incontenible en la historia. Anteriormente el pueblo hitita llegó a Anatolia, en torno a la mitad del III milenio a. de C., por el Bósforo. Entre los primeros en llegar hay que citar a los luwitas, predecesores de los hititas, es decir, los indoeuropeos que luego ocuparian Hattussas y constituirian el imperio. Hacia el 1900 a. de C. los protogriegos siguen la misma ruta, pero en lugar de cruzar el Bósforo hacia Anatolia, continúan hacia el sur hasta el Peloponeso, estableciéndose en la actual Grecia. Los celtas e itálicos migran hacia el oeste, quedándose en Europa occidental e Italia, respectivamente. Los arios migran hacia el este, a través de las estepas de Rusia meridional, hasta la zona del mar de Aral y el río Amu-Daria, desde donde unos, los iranios, avanzan hacia el sudoeste (persas, medos, etc.) y otros, los indoarios, lo hacen hacia el sudeste, atravesando el río Amu-Daria, los altos pasos del Hindu-Kush y el Khyber y penetrando por el noroeste en el valle del Indo ${ }^{19}$.

18 Ver G. DumÉzIL, Los dioses de los indoeuropeos, Seix Barral, Barcelona, 1970.

19 Véase J. Mosterín, ob.cit., pp. 8-9 
La antigua literatura védica - la que se relaciona con el Rigveda y otros escritos sagrados antiguos - da testimonio de los duros enfrentamientos de los arios contra los dasyu o dasa (esta última palabra adquiere posteriormente el significado de "esclavo"), en los que es posible adivinar a los supervivientes de la civilización del Indo. Son descritos como gentes de piel negra, «desnarigados" ${ }^{20}$, «sin nariz", «rechonchos» - a veces "monos"-; adoradores del falo, lo que alude a la raíz prearia del posterior culto hindú del falo, o lingam. Habitaban en poblados fortificados (lo que se deduce, por ejemplo, del hecho de que el dios védico Indra tenga el sobrenombre de purandara, "destructor de fortalezas") ${ }^{21}$.

En muchos aspectos los arios estaban culturalmente atrasados respecto a las ciudades del Indo. Ignoraban la escritura, no habitaban en ciudades y sus técnicas agrícolas eran bastante primitivas. A pesar de la superioridad numérica de los indígenas respecto de los arios, éstos presentaban una mayor capacidad bélica: ligeros carros de combate, armas de bronce bien trabajadas, etc. Los restos de la cultura de Harappa, la más importante de esas ciudades-fortaleza de los indígenas, desaparecieron y los arios acabaron dominando el país.

Entre el 1500 y el 850 a. de C. aproximadamente, los arios ocuparon el noroeste de la India, estableciéndose entre los ríos Satlaj (afluente del Indo) y Yamuna (afluente del Ganges), en una región correspondiente a los actuales Punjab y Haryana. El trueque era práctica común en el comercio, y la vaca era la unidad de valor en los transacciones grandes. De los otros animales que criaban, un lugar privilegiado correspondia al caballo ${ }^{22}$.

Los arios estaban divididos en un principio en las tres clases indoeuropeas: los ksatriyas (aristocracia guerrera), los brahmanes (sacerdotes) y los vaisya (agricultores y artesanos). Posteriormente se añadió una cuarta, la de los sudra (siervos), constituida por los indígenas integrados o sometidos. Nos encontramos en presencia de una división esencial en la sociedad india. Esta división en cuatro grandes grupos llamados varna (palabra sánscrita que significa "color») debía, a través de sucesivas fragmentaciones originar el "sistema de las castas" de la India clásica ${ }^{23}$.

20 Este nombre se refiere al tipo de nariz australoide, con un puente cóncavo, que hallamos todavía en muchos indios de ascendencia dravídica, debido probablemente a cruces con los aborigenes.

21 Ver E.O. JAMES, Historia de las religiones, Ed.cit., p. 235.

22 Véase A.T. EMBREE y F. WILHELM, Historia del subcontinente desde las culturas del Indo hasta el comienzo del dominio inglés, en Historia Universal, Siglo XXI, Madrid, 1974, pp. 19-21.

23 Ver R. Thapar, Historia de la India, Fondo de Cultura Económica, México, 1969, Vol. I, p. 40. 
Durante los primeros siglos de su dominación, los arios no habían alcanzado todavía el estadio urbano. La unidad social básica era aún el grama, palabra que, en la época, significaba un grupo de familias, y más tarde la aldea.

El grama era, en aquella época, un grupo nómada que se desplazaba con sus servidores y sus rebaños a las órdenes de un gramani (jefe de carruajes). No sólo las rivalidades entre los grama eran frecuentes, sino que la noción de realeza o de soberanía era muy vaga y, de todos modos, los poderes del rajan (jefe tribal o rey), estaban claramente delimitados por una especie de derecho consuetudinario.

\subsection{Imperios e invasiones}

Los siglos durante los cuales los arios se expandieron hacia el este de la India, formaron sus pequeños reinos y lucharon entre sí se reflejan en los grandes poemas épicos Mahabharata y Ramayana, consignados por vez primera por escrito en el $1300 \mathrm{~d}$. de $\mathrm{C}$., aunque al parecer se elaboraron entre el 1000 y el $700 \mathrm{a}$. de $\mathrm{C}$.

Alrededor del 600 a. de C., en el norte de la India surgieron dieciséis estados, desde Gandhara en el noroeste hasta Anga en el bajo Ganges. Se han excavado algunas ciudades de estos estados, conocidas por los poemas épicos. Dichas ciudades incluyen Hastinapura, punto de partida del Mahabharata; Kosam, Magadha, que más adelante se convirtió en la monarquía más poderosa de la llanura del Ganges.

A finales del siglo VI a. de C., Gandhara pasó a formar parte del Imperio persa, y su capital, Taxila, se convirtió en centro intelectual del saber védico y del iranio. Con el transcurso del tiempo, la influencia de las ideas persas se dejó notar en distintos ámbitos de la vida india.

Entre el advenimiento de los arios y la aparición de los grandes reformadores religiosos - Gautama el Buda y Mahavira o Jina-, en el siglo VI a. de C., en el norte de la India se produjeron transformaciones profundas. La sociedad dejó de estar organizada en tribus, se crearon estados y prosperaron ciertas instituciones sociales y religiosas de raíz aria, como el sistema de castas y el hinduismo. El sánscrito fue durante los dos mil años siguientes la lengua de la tradición sacerdotal, la lengua franca de los indios hablantes de dialectos (prákritos) distintos, la lengua de la administración, la religión, la ciencia, la filosofía, etc. A medida que la tecnología del hierro se difundió, gran parte del terreno fue desbrozado para practicar la agricultura a gran escala, y el arroz se cultivó intensivamente en el valle 
del bajo Ganges. Con la aparición de la vida urbana tuvieron lugar acelerados cambios sociales y económicos.

En el siglo VI evolucionaron dos clases de estados políticamente organizados a partir del anterior sistema tribal de los arios. En las repúblicas se mantuvo la antigua tradición tribal de las asambleas representativas y los funcionarios electos. En las monarquias tuvo una gran influencia el brahmán (sacerdote), cuyos sacrificios y rituales eran indispensables para atribuir divinidad al rey. La interdependencia de monarca y sacerdote evolucionó con la aparición de la monarquía divina y hereditaria, y en estos estados los sacerdotes impusieron con todo rigor las antiguas tradiciones védicas.

En el transcurso de dicho siglo se desarrolló el comercio, quizá con el estímulo de la utilización de monedas, que se propagó desde las regiones gobernadas por los persas. Posiblemente por la misma ruta la escritura fue reintroducida en la India. Fue un período de conflictividad social, en las que las aspiraciones de los grupos urbanos en reciente ascensión, tropezaron con la ortodoxia establecida. Ya existía la tradición de sabios y ascetas que llevaban una vida de recogimiento, soledad y meditación. Como reacción de los grupos de la sociedad para los que la teología existente no se adecuaba a sus expectativas vieron la luz una gran variedad de filosofías y corrientes.

De todas las corrientes, sólo el budismo y el jainismo se convirtieron en religiones independientes. Sus máximos representantes eran coetáneos. Ambos desaprobaron el sistema de castas y la importancia que los sacerdotes concedian al ritual, especialmente a la práctica de sacrificios como camino de salvación.

Mahavira, el profeta de la religión jainista, procedía de una familia aristocrática de Vaisali; no es considerado su fundador, sino el predicador o apóstol de esta doctrina. A los treinta años se convirtió en asceta errante. Como el budismo, el jainismo enseña la renuncia del mundo a través del comportamiento moral. El jainismo reconoce la existencia de almas individuales que están ligadas a la materia y que en el curso de las reencarnaciones se manchan por las acciones terrenas, y vuelven a mancharse de nuevo. Purificar y mantener limpias estas almas por medio del cumplimiento de los cinco mandamientos, encabezados por el de «no matar», y por el de la "penitencia", es la vía para liberarse del ciclo de las reencarnaciones (samsara).

La doctrina fundada por Siddharta Gautama conocido como el Buda (el "lluminado") se convirtió en una de las grandes tradiciones religiosas del mundo. Nacido hacia el años 566 a. de C. llevó una vida de noble rico hasta que cumplió veintinueve años. Según la tradición halló la iluminación tras una larga meditación bajo una higuera. En adelante, en el transcurso 
de un largo ministerio como predicador errante, enseñó las "Cuatro Verdades Nobles» y el "Noble Camino Óctuple». Formó una Comunidad que fueron engrosando discípulos mendicantes procedentes de todas las castas, mujeres y laicos devotos ${ }^{24}$.

En la India propiamente dicha el budismo se extinguió alrededor del $1200 \mathrm{~d}$. de C., aunque algunos distritos, como Magadha, Bengala, Orissa y la India meridional se mantuvo durante 300 años más.

La India hace su entrada en la historia escrita ${ }^{25}$ coincidiendo con la invasión de Alejandro Magno (326-325 a. de C.). En su breve estancia, Alejandro dividió el valle del Indo en satrapías, estableciendo en lugares estratégicos ciudades amuraliadas con núcleos de población griega, segregada de su propio ejército. Sin embargo, tras su prematura muerte, ocurrida en el año 323 a. de C., los gobernadores de éstas abandonaron el país, y es probable que arrastraran consigo a los soldados que habían quedado como colonos.

Entre el 324 y el 317 a. de C., Chandragupta, un joven aventurero maurya, derrotó al último rey de los Nanda y se hizo con el trono de Magadha. Consiguió apoderarse de la región del Indo y tras derrotar a Seleuco Nicátor, sucesor de Alejandro, estableció un imperio desde Herat hasta el golfo de Bengala.

El prestigio de la dinatía maurya se mantuvo con los sucesores de Chandragupta, sobre todo, con Asoka (aprox. 264-226 a. de C.). Una sangrienta campaña militar hacia el Este y la conquista, a costa de grandes pérdidas, de Kalinga (260 a. de C.), fue lo que, según el Edicto en la roca XIII, movió al rey a abandonar toda conquista ${ }^{26}$.

Con la decadencia del imperio maurya, hacia el año 184 a. de C., los griegos de la Bactriana (colonia griega fundada por Alejandro) cruzaron el Hindu Kush y se asentaron en Kabul y en el Punjab ${ }^{27}$.

Divididos en pequeños reinos, poco a poco los indogriegos cedieron el paso a los sakas, antiguos nómadas del Asia Central conocidos también

24 Ver M.T. ROMÁN, "BUDA: un personaje para la historia del antiguo oriente", ESPACIO, TIEMPO Y FORMA, UNED, Madrid, 1994.

25 Hacia el siglo IV a. de C. comienza a usarse el sistema de escritura llamado brahmi.

26 Véase AsokA, Edictos de la Ley Sagrada, trad. F. Rodríguez Adrados, EDHASA, Barcelona, 1987.

27 El gobernante indogriego más célebre fue Menandro (aprox. 155-130 a. de C.), que rigió grandes dominios que se extendían desde Afganistán, atravesaban la región fronteriza noroeste y llegaban a Lahore. Con el nombre de Milinda, su fama se ha perpetuado en una obra budista que relata su conversión a esta religión. Véase I.B. HoRner (dir.)., Milinda's Questions, The Pali Texts Society, Oxford, 1991, Vol. 11. 
con el nombre de escitas. Estos llegaron al Punjab en la segunda mitad del siglo I a. de C. y pasaron al Gujarat y a la India Occidental.

Los siguientes invasores fueron los kushanas, una rama de las hordas yue-chih, expulsadas de China a principios del siglo II a. de C. Estos formaron un imperio unido hacia el año 10 a. de $\mathrm{C}$. bajo el mando del rey Kadfises I, el cual atravesó el Hindu Kush y conquistó gran parte del Punjab. El más importante de sus sucesores fue Kanishka (aprox. 120$160 \mathrm{~d}$. de C.), que goza de un lugar privilegiado en la literatura búdicosánscrita por su celo budista y sus construcciones religiosas, celebrándose bajo sus auspicios el concilio budista de Cachemira.

Los Kushanas actuaron de puente entre Oriente y Occidente y fueron contemporáneos del Imperio romano en el apogeo de su riqueza, durante el que hubo una demanda de especias, marfil y otros productos. Además de las rutas terrestres, el comercio también atravesó el océano Indico, con lo cual creó riquezas en el oeste de la India, como lo ponen de manifiesto los monumentos budistas de Sanchi y de otros asentamientos de la zona.

Después de Kanishka, el imperio kushana decae para extinguirse hacia el año 226. Una nueva dinastía nacional, la de los gupta (s. IV d. de C.), alejó a los extranjeros que habían dirigido los destinos de la India sin conseguir reunificarla desde la caída de los maurya, y reemprendió el imperialismo de estos últimos.

Aunque practicantes del hinduismo, en cuestiones religiosas los gupta fueron tolerantes y contaron con muchos asesores budistas. En este clima coexistieron diversas religiones y sectas. Durante esta época adquirieron su forma definitiva en sánscrito las dos grandes epopeyas indias: el Mahabharata y el Ramayana.

Hacia el final del siglo $V$ d. de $C$., la India sufrió el ataque de los hunos, que desde su cuartel general de Bamiyan, cerca de Herat, invadieron el Asia Central, Europa Oriental, Persia y Afganistán. Sus correrías se fueron convirtiendo en migraciones y asentamientos, y así, hacia el año $500 \mathrm{~d}$. de C. se estableció un imperio huno en Malva. Ante estos ataques el imperio gupta se disolvió. A su vez, el dominio de los hunos en Asia Central se derrumbó hacia la mitad del siglo $\mathrm{VI}$ d. de C. y con él desapareció su imperio indio.

\section{LAS CREENCIAS MÁGICO-RELIGIOSAS DEL HINDUISMO}

\subsection{Los orígenes mágicos del pensamiento hindú}

Aproximarse al pensamiento hindú implica entrar en contacto con sus orígenes mágicos. El Indostán parece que estuvo habitado, según la etnología 
moderna, por las primitivas tribus munda de las que actualmente quedan algunos supervivientes, tales como los kols y los santal del Chota Nagpur. Las creencias religiosas de estas poblaciones parecen ser el totemismo, la vida de cada individuo unido con un animal o una planta. Esta concepción de la comunión con la naturaleza, de la unión totémica del sujeto con el universo y, sobre todo, con el mundo vegetal, sobrevivirá en una forma espiritualizada y abstracta.

Según Rivière, en esta época, todo presenta tintes mágicos; la eficiencia material y automática del ritual, el poder de la fórmula exacta, del gesto mágico y de la voz humana constituyen el fundamento de las concepciones primitivas predravidianas y dravidianas ${ }^{28}$; los cultos de este período de tiempo tuvieron un gran eco en las creencias religiosas de los hindúes.

Casi todas las deidades de los drávidas parecen haber sido femeninas, revelando de este modo el poder del "matriarcado" $y$, de forma indirecta, de la mujer.

"Se sabe que desde la Capadocia hasta el Golfo de Bengala, la organización familiar de los primitivos consistió en la descendencia matronímica, en el cual el nombre, los bienes y los honores se transmitieron por la madre, constituyendo éste el núcleo a cuyo alrededor giraba toda vida social. Este predominio femenino se percibe en el poder de las diosas dravidianas, cuyos restos se ven todavia en los cultos de Kali, la negra, de Durga, la cinaccesible", en los cuales la sangre del sacrificio riega las estatuas bárbaras y primitivas de las diosas gesticuladoras; ritos éstos tan lejanos de los conceptos habituales arios" 29 .

Estas divinidades «bebedoras de sangre» representan las fuerzas salvajes e implacables de la naturaleza. Estas fuerzas creadoras fueron simbolizadas con el lingam, el miembro viril, destructor y creador al mismo tiempo, cuyos atributos se expresan en Shiva, dios clásico que recibió la herencia de este vestigio cultural primitivo, siendo, por tanto, una divinidad andrógina la que está al principio de estas creencias. Esta creencia religiosa, unida al suelo, perduró en forma de supersticiones populares en las poblaciones bajo dominio ario y fue predominante en los poco lugares donde la influencia aria no llegó.

Ya vimos que en el valle del Indo, antes de la llegada de los arios, existió una civilización próspera sumero-dravidiana que fue el puente entre la cultura mesopotámica y la India: el culto de un dios celeste y de una 
diosa madre se observa en el Ahura iranio -el Varuna védico que se vuelve a hallar en el Asura (= Ahura) védico parecido al Ashur asirio- ${ }^{30}$. El hallazgo de las ruinas de Mohenjo-Daro en el Sindh, podría ser un valioso testimonio de la existencia de ese puente. Pero, ¿qué fue de las creencias de esta civilización prearia? Nada conocemos de esta síntesis sumerodravidiana puesto que no se han conservado testimonios, leyendas o tradiciones de este período.

La escritura de Harappa y de Mohenjo-Daro no ha sido descifrada aún, pero el parecido entre los sellos de estos lugares con los de Susa, ponen en evidencia las posibles relaciones existentes, hacia el año 3000 a. de C., entre la civilización de Sumer y la India del norte. Para Rivière:

"Los dibujos de los toros, la forma de la escritura, la semejanza de los trabajos agrícolas, confirman esta hipótesis. Estas relaciones pueden tener un triple origen: sea que existieran relaciones culturales entre los arias hindúes y los pueblos de Mesopotamia, lo cual parece confirmado por el uso de nombres de dioses arias en textos mesopotámicos (Boghazkoi) sea que hubiese uno o varios Estados en los cuales se utilizase la escritura de Sumer (Estados que fueron destruídos por los arias invasores); sea, en fin, que la civilización de Mohenjo-Daro fuese de origen sumerio, lo cual confirmaria la teoría de H.R. Hall de que los drávidas fueron un pueblo de Mesopotamia [...] Pero lo único que podemos afirmar es que Mohenjo-Daro indica una civilización prearia, que quizá fue destruida por estos arias bárbaros" ${ }^{31}$.

Las creencias mágicas prearias no son fáciles de describir puesto que no hay pruebas y las ideas que aparecen en los Veda ponen de manifiesto ya un trabajo bastante elaborado por una clase sacerdotal influyente. Hallamos, no obstante, ritos védicos que son mágicos a pesar de que formaban parte del ámbito del sacrificio.

El chamán de estos remotos tiempos aparece siempre alejando los malos espíritus y utilizando fórmulas mágicas para influir sobre la naturaleza. Posteriormente, el sacerdote védico acaparó para sí las dos funciones y el Atharvaveda, que había sido una colección de fórmulas maléficas, fue incluido en el canon védico después de agregarle numerosos himnos del Rigveda.

Entidades maléficas y genios (rakshas, yatu, pishacha) tienen un puesto relevante en los primitivos rituales mágicos de evocación: presentan cuerpos animales y el propio brujo puede adoptar estas formas; en ocasiones se vuelven aves, que surcan los cielos nocturnos. Hay "sustancias"

so Ibid., 28.

31 Ibid., pp. 28-29. 
negativas, peligrosas - tanu-, que tienen un poder maléfico - papmanvuelan y se rigen por el influjo de las estrellas y de la luna.

Se aprecia en la antigua literatura védica un fondo de magia muy parecido al que la etnología nos presenta en las civilizaciones primitivas: son como unos rituales de «magia preventiva», tabú (no escuchar sonidos impuros, tabú de la muerte), ritos de silencio, uso de amuletos confeccionados con partes de árboles sagrados, utilización del agua y del fuego para defenderse contra la brujería y evitar que los demonios incomoden a las personas, utilización de piedras, de plantas, de flechas, de metales. Asimismo se usan medios mágicos para intervenir sobre las fuerzas negativas: ruidos de gong, y de tambores, gestos de limpiar y de barrer; la utilización de imágenes hechas para influir sobre un individuo se halla en todos los pueblos primitivos y también se observa en el período anterior a los Veda; se hacen imágenes de los soldados, de los caballos y de los elefantes del adversario, y posteriormente se los destruye pieza por pieza, a fin de que el enemigo sea abatido. Las enfermedades se curan con fórmulas mágicas ${ }^{32}$.

Éste era el tiempo en que predominaban los rituales mágicos; poco a poco los ritos religiosos, relacionando los seres humanos con las divinidades, ocultaron esta primera capa mágica que se mezcló así en los rituales brahmánicos de una manera inextricable y que se mantienen hasta la actualidad en la vida cotidiana de los hindúes.

\subsection{La literatura religiosa}

El documento religioso más antiguo de la India es una colección de himnos, los $\mathrm{Veda}^{33}$, escritos en un lenguaje que corresponde a la etapa más antigua del sánscrito. Estos textos religiosos se han transmitido de generación en generación, durante largo tiempo y de una manera oral por

32 En este sentido, en el Rigveda hallamos los siguientes versos: "Brillando con una claridad bienhechora, levantándose hoy y subiendo por encima de los cielos, ahuyenta, joh Sol!, la enfermedad lejos de mi corazón y el tinte amarillo lejos de mi cuerpo. Transfiramos el color amarillo de mi cuerpo a los papagayos, a las aves de los bosques, o al árbol Haritala". Vyasa, Los Vedas, Juan A. Bergua, Madrid, 1988, pp. 111-112. Una leyenda india estima que recitándolo de modo adecuado se consigue la curación de las enfermedades que puedan sufrirse. Asimismo dichos versos se consideran como un antidoto contra un veneno y hasta como un amuleto que puede procurar la dicha y la liberación final.

33 Ver VYASA, ob.cit., F. VILLAR, Himnos Védicos, Editora Nacional, Madrid, 1975, J.M. DE Mora (dir.), El Rig Veda Samhita, Edamex, México, 1990. Sri Sampurnanand (dir.), The Athana Veda Vratyakanda, Ganesh and Co., Madras, 1956. 
recitadores profesionales. Se consideraban escritos por hombres o mujeres llamados rishis ("videntes"), que en tiempos muy lejanos los recibieron por inspiración directa de los dioses; a causa de lo cual estos sabios-videntes dieron al conjunto de textos objeto de favor tan especial el nombre de Sruti ("Revelación»), nombre con que se designa el Veda.

La antigüedad y el lugar de origen de esta literatura han sido ampliamente debatidos, y las fechas varían mucho según las bases astronómicas, históricas o literarias de estas hipótesis; van del 4000 al 5000 a. de C. (Tila K. Jacobi), al 1200-1000 a. de C. (Max Müller), pasando por el 2000 a. de C. (Hang, Whitney). Según H. von Glasenapp: «La apreciación más verosimil admite que, en su parte principal, esos textos van más allá del año 1000 a. de C., pero no se puede determinar si los poemas más antiguos fueron compuestos en 1250, 1500, 2000 a. de C. O aún antes" ${ }^{34}$.

La literatura védica comprende cuatro colecciones (samhita) que son: el Rigveda, o "Veda de las estrofas"; el Samaveda, o "Veda de las melodías»; el Yajurveda, o "Veda de las fórmulas"; el Atharvaveda, o "Veda de los encantamientos"; estas cuatro constituyen el Veda propiamente dicho. Los Brahmanas, los Aranyakas y los Upanishads son comentarios posteriores que se elaboraron sobre los Veda y representan ya una especulación de altos vuelos.

La única parte de la literatura védica que claramente corresponde al período temprano es el Rigveda. Se trata de una colección de himnos en honor de las divinidades compuesta por los sacerdotes indoarios aproximadamente entre el 1500 y el 900 a. de C. Los himnos eran recitados por los sacerdotes durante los sacrificios rituales y su objetivo era granjear el favor de las divinidades para que éstas otorgasen: salud, riqueza, descendencia y victoria sobre los enemigos. Las deidades eran halagadas con loas y casi sobornados con ofrendas y con el soma, licor fermentado de una planta aún desconocida ${ }^{35}$.

La lengua del Rigveda es muy arcaica y ya hacia el 500 a. de C. presentaba considerables dificultades de comprensión. No obstante, el carácter totalmente sagrado de estos himnos ha asegurado su transmisión oral fidedigna hasta la época actual. Con la introducción de la escritura fueron también fijados por escrito.

El Rigveda consta de 1017 himnos, a los que hay que añadir los once finales, que reciben el nombre de Valakhilya. Los libros II-VII son denominados

34 H. von GlasenapP, La filosofía de los hindues, Barral, Barcelona, 1977, p. 45.

35 Ver P. DE FELICE, Venenos sagrados. Embriaguez divina, Felmar, Madrid, 1975, pp. 197-215. 
mandala familiares y forman el núcleo más antiguo. Dentro de cada mandala los himnos se encuentran agrupados por la divinidad a que van dirigidos, y dentro de los himnos a cada deidad, se ordenan por el número de estrofas de mayor a menor. El libro VIII y los cincuenta primeros himnos del libro primero son atribuidos a la familia de los Kanvas. El libro IX está dedicado al dios Soma. El libro I, y en particular el X, deben ser considerados comparativamente más recientes, por sus peculiaridades lingüísticas, gramaticales y métricas, y también por las ideas abstractas y filosóficas que en ellos concurren ${ }^{36}$.

En los libros familiares el primer grupo está siempre dirigido al dios Agni, el segundo al dios Indra, los restantes a deidades de menor relevancia. Así, pues, los dioses más favorecidos son los mencionados, poseyendo Soma más de 100 himnos, Agni unos 200, Indra más de 250.

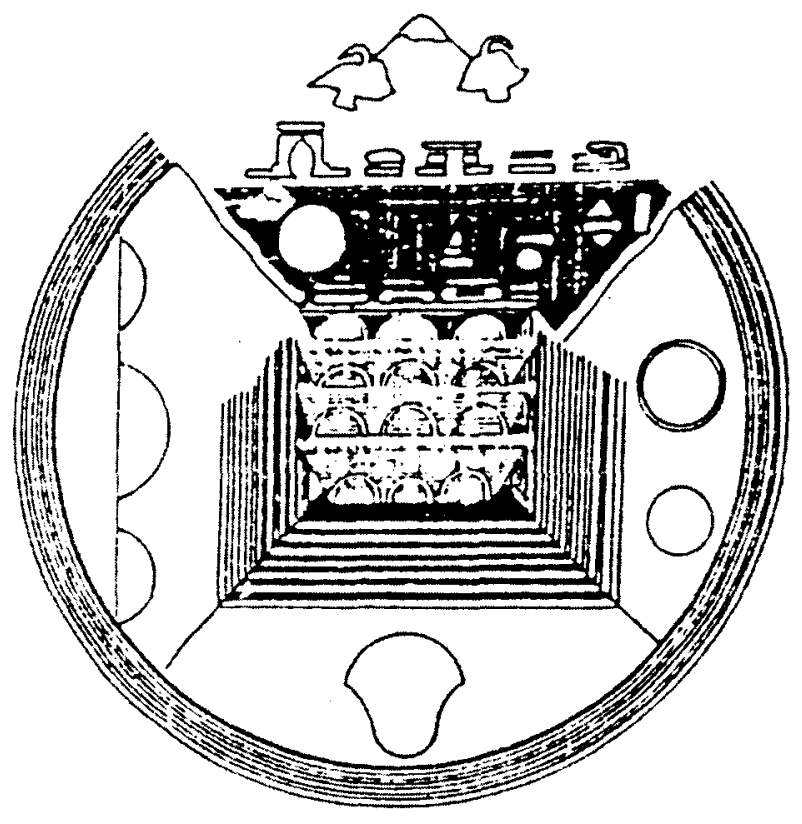

Figura 4. Mandala. 
De la totalidad de los himnos (el Rigveda tiene 1028), sólo unos cuantos no están dirigidos a los dioses u objetos divinizados. De esta minoría unos 12 contienen ritos mágicos; otros son a modo de poemas seculares relativos a usos sociales, temas morales, enigmas y especulaciones cosmogónicas; algunos tienen un gran interés por los datos consignados sobre la primitiva civilización india.

Los himnos védicos proporcionan información para un detallado conocimiento de las condiciones sociales de aquellas épocas lejanas. En ellos se observa que la familia era el sostén y la base de la sociedad, con el padre por jefe, y que la mujer era más libre y más respetada que en épocas posteriores. Se dan diversos detalles sobre indumentaria y adornos personales, sobre los distintos tipos de manjares y sobre bebidas, de las que el soma se reservaba para los rituales religiosos, en tanto que el sura, extraído de cierto cereal, era de un uso corriente. Se describen las principales ocupaciones de los arios invasores, entre ellas la guerra; la cría de ganado, una de sus más importantes fuentes de riqueza; la navegación en botes movidos por remos; los arios sentían profundamente la música, siendo sus principales instrumentos el tambor, la flauta y el laúd.

El ritual védico y brahmánico han extraído sus textos y oraciones de este conjunto de himnos. Algunos himnos tratan de descifrar el enigma del mundo y afirman ya la existencia de un pincipio único de quien las divinidades son múltiples figuraciones.

A continuación viene el Samaveda, o «Veda de los cantos» ${ }^{37}$, que nos ha llegado en tres versiones; el texto está dividido en tres partes. Es la recopilación de los cantos (saman) que debía aprender el sacerdote cantor (udgatar) y entonarse en el coro del sacrificio. Los versículos, hasta un total de 1810, están extraídos del Rigveda en su mayor parte. Algunos samana debían ser "cantados" en el bosque», pues eran sagrados y tenían un poder mágico que les hacía peligrosos y temibles para ser oídos en las reuniones.

La tercera colección es el Yajurveda, o "Veda del oferente", que comprende las fórmulas que se recitaban en los sacrificios. Esta colección existe en dos versiones: el Yajurveda blanco, que contiene sólamente las fórmulas y las plegarias, y el Yajurveda negro, en el cual las fórmulas aparecen acompañadas de un comentario tradicional que explica su sentido místico. Estas fórmulas de los sacrificios, los yayus, estás escritas en prosa o bajo forma métrica; contienen desde cortas oraciones hasta largas

37 Ver VYASA, ob.cit., pp. 398-594. 
letanías. Son los testimonios más antiguos que nos han llegado de la prosa hindú y presentan un gran interés para el análisis de la forma antigua de la religión védica.

El cuarto Veda es el Atharvaveda, o "Veda de los magos atharvanas» ${ }^{38}$, colección de versos en relación muy estrecha con la función de sacerdote doméstico; trata de la ciencia de las fórmulas mágicas, parte en verso, parte en prosa, para poder conseguir distintas ventajas y poder defenderse de las potencias hostiles.

El Atharvaveda es el más reciente de todos los Veda y durante mucho tiempo ocupó un puesto secundario en relación con los otros Veda. En este Veda aparece ya, en germen, la organización de los brahmanes y su supremacia.

Parte de los contenidos del Atharvaveda, pudo haberse originado entre las clases más bajas de las tribus arias; en su mayoría procede posiblemente de fuentes aborígenes. Los dioses védicos de los arios apenas desempañaban papel alguno en esta literatura; los contenidos cosmológicos están más acorde con los de los Upanishads que con los de los himnos primitivos del Rigveda. Así, por ejemplo, el himno a la Diosa Tierra, una de las más características composiciones de los himnos del Atharvaveda. Pero, por lo general, el Atharvaveda contiene temas domésticos, y si alguna vez traspasa este ámbito, es para quedarse en el dominio de las funciones y de las relaciones sociales.

Las materias de las que se ocupa son: hechizos para curar dolencias y procurar la salud y la inmunidad; imprecaciones contra los demonios y brujos; hechizos en beneficio de la mujer - para conseguir un marido o tener un hijo- o en beneficio del hombre - para asegurarle el amor de una mujer o para conseguir el regreso de una esposa frivola-; hechizos dirigidos al rey, a su consagración y al triunfo en sus empresas; hechizos referidos a las relaciones personales en general -en defensa de la armonía, para apaciguar las discordias y para aplacar la ira-.

En la sociedad védica tardía, ya sedentarizada y económicamente más evolucionada, el grupo sacerdotal se fue profesionalizando en las complejas técnicas del sacrificio y de la liturgia. Los himnos del Rigveda dieron paso a una reflexión más prolija y escolástica sobre los detalles rituales del culto, de su justificación y significado. Esta reflexión sacerdotal se recoge en los Brahmana.

38 Ver Sri SAMPURNANAND (dir.), ob.cit. 
Los Brahmana son unos extensos tratados teóricos relacionados con cada uno de los Veda y explican y justifican los ritos y las fórmulas empleadas; es el resultado de la labor interpretativa y de la glosa de generaciones de sacerdotes, que ha sido clasificado sistemáticamente. Fueron compuestos aproximadamente entre los siglos X-VII a. de C. y corresponden al poderío creciente de la casta sacerdotal sobre la sociedad aria. Se encuentra en ellos una doctrina profunda del sacrificio, primer estado de la metafísica india. El texto más importante es el Satapatha Brahmana, el "Brahmana de los cien caminos», relativo al Yajurveda blanco; los misterios del Soma y del Fuego son comentados en este texto con una amplitud que anuncia ya los Upanishad.

A los Brahmana se unen los textos ritualistas y místicos de los Aranyaka, o "tratados del bosque", y los Upanishad ${ }^{39}$. Los primeros son libros secretos, mágicos, que incorporan las fórmulas (mantra) y los ritos particulares sagrados y peligrosos para el profano; como medida de precaución, la enseñanza y los rituales se llevaban a cabo lejos de los centros poblados, en el aislamiento de la naturaleza.

Según la etimología más difundida el nombre Upanishad procede de upa ("alguien»), ni ("junto a») y sad ("sentarse»); es decir, la acción de sentarse el discípulo junto a su maestro o gurú para escuchar lo que éste confidencialmente le transmitía. Finalmente acabó por darse al término Upanishad el sentido de doctrina secreta. En realidad los Upanishads son los textos que constituyen la parte final de la Sruti (la "Revelación») y sientan los fundamentos del Vedanta, las conclusiones filosóficas procedentes de los Veda, y como tales su finalidad era ayudar a entender el significado de las complicadas acciones rituales, etc. de la religión védica, tal como se prescriben en los Brahmana.

La mayoria de los Upanishad son obras bastante breves; su redacción que comienza hacia los siglos VIII-VII a. de C., prosigue hasta la Edad Media. De ellos arrancan la mayor parte de las seis escuelas filosóficas indias ${ }^{40}$.

Los principales Upanishad se clasifican en tres grupos. El primer grupo, que es el más antiguo, compuesto aproximadamente durante los siglos VII a V a. de C., contiene seis Upanishad, escritos en prosa y con un estilo arcaico. Son los siguientes: Brihadaranyaka, Chandogya, Aitareya, Kaushitaki, Kena y Taittiriya.

39 Véase F. TOLA, Doctrinas secretas de la India Upanishads, Barral, Barcelona, 1973.

40 Ver H. von GlasenAPP, ob.cit., pp. 157-268. 
El segundo grupo fue compuesto aproximadamente durante los siglos $\mathrm{V}$ al III a. de C. en sánscrito clásico y en verso y son: Katha, Isha, Shevetashvatara, Mundaka y Mahanarayana.

Además de estos textos, hay numerosos Upanishad, de los cuales los más importantes se refieren al Yoga y a las prácticas ascéticas; ordinariamente se cuentan treinta principales o mayores; los más importantes son: Atmabodha, Narayana, Maha, Atharvashiras, Kaivalya, Brahmavidya, Aruneya, Sannyasa y Yogatattva.

El contenido de estos textos es muy variado; tratan de problemas psicofisiológicos, de cosmogonia, de metafísica, estableciendo la gran «revelación» brahmánica de la equivalencia del Brahman, el universo, con el atman, el alma individual.

El cuadro que viene a continuación, nos muestra los distintos textos de la literatura védica.

\begin{tabular}{|c|c|c|c|c|c|}
\hline Vedas & & Samhitas & Brahmanas & Aranyakas & Upanishads \\
\hline \multicolumn{2}{|l|}{ RIGVEDA } & $\begin{array}{l}\text { Shakala } \\
\text { Vashkala }\end{array}$ & $\begin{array}{l}\text { Aitareya } \\
\text { Kaushitaki }\end{array}$ & $\begin{array}{l}\text { Aitareya } \\
\text { Kaushitaki }\end{array}$ & $\begin{array}{l}\text { Aitareya } \\
\text { Kaushitaki }\end{array}$ \\
\hline \multicolumn{2}{|l|}{ SAMAVEDA } & $\begin{array}{l}\text { Kauthuma } \\
\text { Ranayaniya } \\
\text { Jaiminiya }\end{array}$ & $\begin{array}{l}\text { Tandya } \\
\text { Shadvinsha } \\
\text { Chandogya } \\
\text { Arsheya } \\
\text { Jaiminiya }\end{array}$ & & $\begin{array}{l}\text { Chandogya } \\
\text { Kena }\end{array}$ \\
\hline \multirow[t]{2}{*}{ YAJURVEDA } & Negro & $\begin{array}{l}\text { Kathaka } \\
\text { Taittiriya } \\
\text { Maitrayani }\end{array}$ & $\begin{array}{l}\text { Kathaka } \\
\text { Taittiriya } \\
\text { Maitrayani }\end{array}$ & Taittiriya & $\begin{array}{l}\text { Katha } \\
\text { Taittiriya } \\
\text { Mahänärayana } \\
\text { Shvelashvatara } \\
\text { Maitriyana }\end{array}$ \\
\hline & Blanco & $\begin{array}{l}\text { Madhyandina } \\
\text { Kanva }\end{array}$ & Shatapatha & Brihadaranyaka & $\begin{array}{l}\text { Brihadaranyaka } \\
\text { Isha }\end{array}$ \\
\hline \multicolumn{2}{|l|}{ ATHARVAVEDA } & $\begin{array}{l}\text { Shaunaka } \\
\text { Paipparada }\end{array}$ & Gopatha & & $\begin{array}{l}\text { Mundaka } \\
\text { Prashna } \\
\text { Mandukya }\end{array}$ \\
\hline
\end{tabular}

Junto a la Sruti (la «Revelación»), toda clase de textos diversos se esfuerzan por elaborar la tradición primordial; su autoridad, aun siendo menor que la del Veda, goza no obstante de gran prestigio. Esta literatura 
forma la Smriti ${ }^{41}$, la tradición confiada a la memoria, que comprende, los Vendanga, miembros auxiliares del Veda, obras de exégesis. Es un conjunto de aforismos, los sutras, de textos escolásticos o comentarios relativos al culto; la tradición los clasifica en seis ramas: astronomia, métrica, ritual, gramática, fonética y etimología. Cada forma del Veda tiene sus propios sutras, cuyo objetivo es ordenar las prescripciones del ritual y presentarlas de una manera asequible para su enseñanza.

Entre los siglos III a. de C. y III d. de C., aproximadamente, la tradición brahmánica ortodoxa se recuperó y floreció de nuevo. Su más espectacular manifestación la constituyen las dos grandes epopeyas, el Mahabharata ${ }^{42}$ y el Ramayana ${ }^{43}$, compuestas durante esa larga etapa por varias generaciones de autores.

El Mahabharata o el Mahabharatakhyanam ("Narración de la Gran Guerra de los Bharatas"), es la epopeya más vasta de la literatura mundial; comprende cerca de 100.000 versos repartidos en 18 libros. Su redacción se sitúa aproximadamente entre el siglo IV a. de C. y los primeros siglos de nuestra era. El tema, sin duda fundamentado en acontecimientos históricos, es la lucha entre dos ramas de la familia bharata: por una parte los kauravas; de la otra sus primos los pandavas. La obra incluye también dos largos tratados filosófico-morales: el monólogo de Bhima poco antes de morir y el Bhagavadgita, o "Canción del Señor» ${ }^{44}$. En él interviene el dios Krishna en forma humana y viene a ser una especie de resumen de las especulaciones religiosas hindúes y de técnica mística. Se cree que el Gita fue compuesto y añadido al gran poema antes del siglo III a. de C.

El Ramayana, o "Gesta de Rama", es una epopeya que, en comparación con el Mahabharata, muestra ya una sociedad cortés y algunos refinamientos literarios. Es también más corta, pues consta de 25.000 dísti$\cos$. Se atribuye a Valmiki, aunque no parece obra de un autor único, y su composición definitiva puede situarse hacia el siglo IV a. de $\mathrm{C}$. El héroe del poema es Rama, quien con actos sobrehumanos y fantásticos libera a su patria de amenazas y de malos gobernantes.

Equiparados en categoría a los Veda, los puranas son una clase de literatura análoga a la épica. Se distinguen 18 puranas mayores y 18 puranas

41 La Smriti continúa de hecho las especulaciones del Veda, pero puede discutirse, modificarse, interpretarse, mientras que la Sruti es inmutable e intangible, por no ser obra humana según la tradición ortodoxa brahmánica.

42 Véase VYASA, Del Mahabharata, Diana, México, 1974.

43 Ver Tulsidas, El Ramayana, Visión Libros, Barcelona, 1981.

44 Véase GANDHI, El Bhagavad-Guita de acuerdo a Gandhi, Kier, Buenos Aires, 1977. 
menores, todos atribuidos a Vyasa. En ellos se encuentran, a la vez, leyendas mitológicas, descripciones de fiestas, de peregrinaciones, comentarios sobre los ritos y los sacrificios, genealogías, etc.

Hay que añadir el grupo de textos sagrados de ciertas escuelas hindúes conocidos con la denominación de agamas shivaítas, de samhitas vishnuítas o de tantras propiamente dichos, que se ocupan ante todo de marcar las directrices para el culto a las deidades, describiendo y explicando el ritual con consideraciones filosóficas predominantemente no dualistas y vedánticas. Los tantras se componen de 64 obras cuyo origen parece haber estado en Bengala y Assam, y comportan enseñanzas de técnicas de yoga y de magia.

Por último debemos citar los textos sobre las instituciones y las prescripciones jurídico-religiosas conocidas con el nombre general de DharmaShastras. El más célebre de todos es el Manava-dharma-shastra, conocido bajo el nombre de Leyes de Manu. Las fechas de la elaboración de estas obras, se suelen fijar alrededor de la Era cristiana.

\subsection{Los dioses hindúes}

\subsubsection{La religión del valle del Indo}

Con la escasa información que tenemos sobre el pensamiento religioso en la civilización del valle del Indo, vamos a tratar de hacer un esbozo, del que probablemente puedan inferirse algunos fundamentos sobre la religión en otras zonas de la India prearia.

La civilización del valle del Indo era básicamente urbana. Más allá del valle del Indo, la norma general más probable, en el momento de la llegada de los pueblos arios, era la de la economía aldeana.

A lo anterior hay que añadir que en gran parte de la India, por lo menos desde los tiempos de la civilización del valle del Indo hasta el momento actual, la agricultura ha representado el pilar básico de la vida del pais. En el ámbito de esta sociedad aldeana, cuya base económica es la agricultura, el culto a la diosa de la aldea aparece como un rasgo más típico aún.

En las sociedades nómadas, de tipo pastoril, abundan los dioses masculinos; entre las poblaciones agrícolas, sin embargo, conocedoras de la fertilidad de la tierra, el acento recae sobre el principio materno.

De este modo, entre los pueblos semitas, cuyas tradiciones son las de los pastores, lo sagrado se contempla en términos masculinos: el dios 
padre; en tanto que las poblaciones indias, cuyo género de vida era de tipo agrícola, personifican a la deidad en términos femeninos: la diosa madre.

Nos encontramos ante un rasgo característico que surgirá constantemente en la historia de la religión hindú: la persistente disposición a contemplar lo sagrado en función de la maternidad. Se podría decir que estamos ante algo intrínseco al alma misma de la India, pues sus moradores se suelen referir al país, llamándolo Madre-India.

Otro factor básico de las creencias religiosas hindúes es el karma, que significa ley de causa y efecto moral de todo cuanto acontece en el universo. No obstante, es en su relación con el hombre cuando el significado de este concepto se clarifica y empieza a contemplarse como uno de los principales elementos del desarrollo de las ideas religiosas hindúes.

En lo relativo al ser humano, el karma quiere decir que lo que un individuo es en su vida actual, está condicionado por sus actos en sus existencias anteriores; de la misma manera, sus acciones en su vida presente determinarán las condiciones de su existencia próxima.

En su obra The Dravidian Element in Indian Culture, Gilbert Slater afirma que el germen de dicha idea probablemente hay que hallarlo en una época en la cual aún no se comprendian los elementos de la reproducción del hombre, sobre todo cuando no se sabia todavía la relación entre coito y concepción:

"Las tribus primitivas, en este estadio de desarrollo, pensaban que la concepción se debía a la penetración de un espíritu en el cuerpo de una joven. Se decia que los espíritus vivían por lo general ocultos en lugares solitarios y apartados, y que las jóvenes que se aventuraban a vagar por tales lugares se exponian a quedar preñadas. La fase siguiente en el desarrollo de tal noción, sería explicar la procedencia del espíritu que habia entrado en el cuerpo de la mujer y producido el feto, y en esie sentido se consideraba que era el de alguna persona muerta recientemente. Así surgió la idea de los espíritus atravesando, vida tras vida, una serie de cuerpos humanos. Fue a impulsos de la evolución que tuvo lugar en la India, cuando empezó a vincularse este intento de explicación biológica con ideas de tipo moral, en el sentido de que el espíritu, en el curso de su transmigración de uno a otro cuerpo, era portador de su propia culpabilidad o mérito moral, que transfería a la vida del nuevo ser humano, cuya buena o mala fortuna, de otro modo inexplicables, parecían tener asi pleno sentido. Por este camino se llegó a una solución satisfactoria para el problema de por qué los hombres sufrian infortunios inmerecidos o, a la inversa, por qué lograban, inmerecidamente también, prosperidad e inmunidad frente al mal. Si un hombre era desgraciado sin causa aparecente, la razón radicaba en las maldades perpetradas en una 
existencia anterior. Si cometia incontables errores y, sin embargo, permanecía indemne, su inmunidad era sólo pasajera; en una existencia futura, su culpabilidad cerniría sobre él su legado de sufrimiento. Una vez elaborada con tales precisiones, la explicación de esta teoría del karma resultó tan satisfactoria que, incluso cuando llegó a conocerse mejor el papel del padre en el proceso de la reproducción, persistió la idea de un espíritu en cuya transmisión se cimentaba la constitución moral del hombre. Tal concepción persiste todavía en la India y en el sudeste asiático" ${ }^{45}$.

\subsubsection{La religión védica}

Cuando los arios penetraron en la India, sus ideas religiosas diferian considerablemente de las de los drávidas ya asentados en dicho país, a lo que hay que sumar la diferente naturaleza de sus divinidades.

La religión védica consiste, en primer término, en una mitología muy elaborada. Las divinidades védicas, tal como las describe el Rigveda, son entes activos que intervienen sin cesar en los asuntos humanos. Convenientemente invocados, obsequiados, con bellas ofrendas, son benévolos y propicios; de lo contrario, peligrosos; y algunos de ellos tienen una naturaleza ambivalente: Rudra, a la vez temible y benéfico cura las enfermedades que él mismo ha provocado.

Los dioses están ligados con las fuerzas naturales; hay dioses principales cuyo poder llena el universo, y dioses secundarios, genios tutelares, locales, objetos deificados. Los textos enumeran treinta y tres dioses: el Rigveda los divide en tres grupos de once divinidades cada uno: el correspondiente al cielo, a la atmósfera y a la tierra. Estas treinta y tres divinidades tradicionales pueden incrementarse con los dioses menores, demonios y héroes divinizados, hasta llegar al número de 3300 deidades de que habla algún himno védico. No pudiendo dar aquí una lista completa de estas divinidades, enumeraremos las principales:

\section{a) Divinidades celestes}

Los dioses de los arios o deva - derivado de la raíz div-, «resplandor": "los resplandecientes" eran básicamente dioses del cielo y dioses masculinos. El primitivo dios indoeuropeo del cielo, Dyaus (identificado con el Zeus griego y con el Júpiter latino) había perdido su papel religioso 
casi totalmente, siendo ahora simplemente el cielo, aunque todavía quedan en los Veda algunos escasos recuerdos suyos, alguna alusión al padre Cielo - Dyaus Pitar- y algún himno conjunto al Cielo y a la Tierra. Durante su larga migración por las estepas euroasiáticas los arios se habían olvidado de Dyaus y lo habían sustituido por Varuna, máxima deidad de los iranios y de los indoarios.

La literatura védica presenta a Varuna como divinidad suprema que rige al universo, a los dioses (devas) y a los hombres: "Oh (dios) sabio, tú riges todas las cosas del cielo y de la tierra" ${ }^{46}$.

Varuna es conocido como un asura ${ }^{47}$, palabra que lo vincula con el Irán, puesto que la forma iraní ahura era la designación zoroástrica de Ahura Mazda, gran "dios de la luz». Varuna es literalmente la deidad «celestial», y su nombre tiene una relación lingüística con el dios griego de los cielos, Urano.

Varuna está asociado al concepto de rita ${ }^{48}$, de orden a la vez físico y moral del cosmos, comparable al maat egipcio, u orden cósmico. Posteriormente dicho orden pasará a denominarse dharma y jugará un papel fundamental en el pensamiento indio.

Otra concepción destinada a florecer en el pensamiento indio posterior y asociado a Varuna es el de maya ${ }^{49}$,que en los Veda significa cambio inducido voluntariamente con magia o truco. Varuna es el señor de la maya, que usa para contrarrestar las malas artes o maya de los enemigos y para crear las nuevas entidades.

Asimismo Varuna garantiza los contratos de los seres humanos, a quienes "ata" por sus juramentos. Varuna es el dios que "ata", privilegio del que gozan también otras divinidades soberanas y que denuncian sus capacidades mágicas, la posesión de un poder de orden espiritual, del poder real por excelencia.

"Pero, sobre todo, es Varuna quien tiene el poder

mágico de ligar y de desligar a los hombres a distancia [...]

46 F. VILLAR (dir.), ob.cit., p.159.

47 El panteón ario parece haber estado originariamente dividido en dos clases: los asura y los deva. En Irán avéstico, los asura (sobre todo Ahura Mazda) se han convertido en los dioses buenos, y los deva en los demonios. En los Veda, por el contrario, los deva son las divinidades buenas; los asuras aparecen como una clase de divinidades, de deva. Posteriormente, asura terminará significando demonio.

${ }_{48}$ Ver M. ElIADE, Historia de las creencias y de las ideas religiosas. De la Prehistoria a los misterios de Eleusis, Cristiandad, Madrid, 1978, V.I, p. 217.

${ }_{49}$ Ibíd., pp. 217-218. 
Varuna está representado con una cuerda en la mano, y en las ceremonias todo cuanto liga, empezando por los nudos, se llama varuniano" 50 .

Cinco son las deidades representativas de los diversos aspectos de la actividad solar: Mitra, Savitri, Surya, Pusan y Visnhú. El más antiguo de éstos, Mitra, parece ser la personificación del poder bienhechor del astro del día. Es una especie de herencia del período indoiranio, pues se identifica con el dios solar persa del mismo nombre, cuyo culto alcanzó tan gran difusión en el Imperio romano en los siglos III y IV a. de C. Mitra aparece poco en los Veda y siempre junto a Varuna, que lo eclipsa como dios soberano.

Savitri, el «estimulante», conductor de las almas de los muertos, ligado al Sol, confiere la inmortalidad a los dioses y la longevidad a los hombres.

Como Savitri, Surya alude al Sol, con el que suele identificarse a menudo. Es el esposo de Usas, la Aurora, que es el alma de todo lo que se mueve. Esta fue cantada especialmente por los poetas védicos.

Pusan relaciona entre sí a todos los seres, móviles e inmóviles. También protege o liberta, asegura el alimento y hace prosperar el ganado, reflejando, quizá, algún viejo rito de fecundidad. Es además, el guardián de los caminos; guía a los muertos a la morada de los antepasados.

Visnhú, que llegará a ser uno de los dioses más importantes del brahmanismo ${ }^{51}$, es, en los Veda, un dios secundario que ayuda a la humanidad en su lucha contra los demonios.

Además de los dioses anteriores, existen otros, los Asvinos, hermanos gemelos de la Aurora, que simbolizan en la India el lucero de la mañana y la estrella de la tarde. Su parecido con los gemelos griegos Cástor y Pólux, hijos de Zeus es tan estrecho, que pueden tener un origen común más o menos remoto.

\section{b) Divinidades atmosféricas.}

Indra es la suprema divinidad en la esfera aérea;dios de la guerra, al que los himnos védicos atribuyen el éxito de la campaña de los arios sobre

50 M. ElIADE, Imágenes y símbolos, Taurus, Madrid, 1979, pp.104-105.

51 Esta palabra ha sido usada de diversas formas para referirse a una determinada religiosidad que aparece en la literatura védica tardía (Brahmana, Upanishad), por constraste con el "vedismo primitivo"; para referirse a la religiosidad propugnada y difundida a partir de esta época por el sacerdocio brahmin, en contraste con el "hinduismo popular"; incluso como sinónimo de "hinduismo". 
sus enemigos; él había sido quien los capacitó para subyugar a los aborígenes urbanos y de piel oscura, llamados dasa. Sin embargo, estaba también ligado con la tormenta, y su arma favorita era el vajra o trueno. Incluso en este severo papel era una deidad benéfica, pues desataba la lluvia encerrada en las nubes y ofrecía humedad a la tierra reseca, manteniendo así a los individuos que la habitaban.

El culto a una deidad de este nombre no es exclusivo de los indoarios, ya que era conocido entre los kasitas que se apoderaron de Babilonia; aparece mencionado en la lista Boghakhoi de deidades adoradas por los mittani y, junto con Varuna y Mitra, es descrito como una de las divinidades de los hurritas que penetraron en Mesopotamia procedentes posiblemente, del Irán.

Su victoria sobre la serpiente Vritra, que tenía prisioneras a las aguas indispensables para la tierra reseca, nos muestra a Indra asociado también a la cosecha. Invocado en las batallas, protector de los arios; símbolo de la exuberancia, la fecundidad, la virilidad, la energía cósmica y biológica, la fuerza y la violencia.

Tres de los dioses menos importantes del aire están relacionados con el relámpago, a saber: Trita, Apam napat y Matarisvan.

Entre los dioses atmosféricos figuran también los Maruts, dioses de la tempestad, hijos de Rudra y de Prisni. El grupo de los Maruts atraviesa el cielo adornado con guirnaldas y brazaletes de oro en carrozas resplandecientes como el sol. En el cortejo figuran Vayu y Vata, personificaciones también de las fuerzas irresistibles del viento. Parjanya es el toro mugiente que cruza la atmósfera dejando caer la lluvia vivificadora. Las aguas (Apah) son seres celestes que moran en la casa de los dioses. Las aguas aéreas son la madre de Apam napat, una de las formas de Agni.

Rudra es otra divinidad atmosférica típicamente india, que encarna una de las intensas perturbaciones atmosféricas características del país. Se la liamó también Sava, y una variante, el epíteto Shiva, iba a convertirse con el tiempo en la terrible divinidad destructora de la Trimurti, que formó con el transcurso de los siglos con Brahma el creador y Vishnú el conservador.

\section{c) Divinidades terrestres}

La más antigua de las deidades terrestres fue Prthivi, la propia Tierra, asociada casi siempre a Dyaus, como divinidad creadora primordial .

El dios terrestre más importante fue Agni, fundamental en la religión védica, aunque su personalidad se complicó tanto, que adquirió el triple 
carácter de celeste, terrestre y acuático, debido a sus múltiples manifestaciones. En su origen Agni era el fuego, sobre todo en su actividad beneficiosa y útil para la vida. Equivale al nórdico Heimdallr, que también es el mensajero de los dioses.

Otros dioses menores son sólo epítetos independizados de los mayores: de los atributos originales de Indra procede Visvakarma, creador del Cosmos; otros equivalen a conceptos abstractos divinizados: Manyu es la cólera (de Indra). No faltan animales y objetos deificados, que son restos de viejos animismos y totemismos; por ejemplo, la tortuga que en época posterior se consideró encarnación de Vishnú. El caballo desempeñaba un importante papel, por ser el que lleva los carros de las deidades. La vaca recibe el tratamiento de diosa. La serpiente destaca entre todos los animales, atribuyéndose su forma al poderoso Vrtra, el enemigo de Indra. Los grandes ríos -el Indo y el Ganges - se celebraron como divinidades femeninas. Entre los héroes, destacamos a Manu, Atharvan, Dadhyand y Kutsa.

Se atribuyen poderes divinos a las plantas. Los árboles llamados vanaspati se consideran a menudo deidades, casi siempre en unión a los ríos y a las montañas. En la religión védica se divinizan varios objetos relacionados con el sacrificio.

Los demonios, a menudo mencionados en los Veda, son de dos clases: la clase superior y más poderosa, los enemigos aéreos de las divinidades, se llaman asuras. La segunda clase, o clase inferior, de entidades demoníacas la forman los duendes, enemigos del hombre, como los asuras lo son de las deidades, y que se conocen por el nombre de raksas. Éstos se encargaban de perturbar el recto orden del sacrificio y de mancillar el fuego sagrado.

La religión védica no se agota con las deidades citadas, hay que añadir legiones de divinidades que constituyen el cortejo de las principales, otras de carácter menor y un sinfín de demonios y espíritus ${ }^{52}$.

\subsection{Siddhi o los «poderes milagrosos»}

Se supone que la práctica del yoga puede proporcionar, como efecto secundario, la adquisición de unos "poderes milagrosos" (siddhl), descritos

52 Ver C. CID, Mitología Oriental llustrada, Vergara, Barcelona, 1962, pp. 437-528. F. GuIRAND (dir.), Mitologia general, Labor, Barcelona, 1965, pp. 451-518. 
en el libro III de los Yoga-Sutra de Patanjali ${ }^{53}$. Entre estos grandes poderes o mahasiddhi, se cuentan generalmente la capacidad de reducirse a dimensiones ínfimas como el átomo, la de tocar a distancia cualquier objeto, una voluntad irresistible, la realización de los deseos, la posibilidad de dominar los elementos, etc.

Sin embargo, en general se admite que estos poderes pueden constituir un mayor obstáculo para la liberación del practicante que los apegos ordinarios a la vida: quien se arriesga por esos senderos puede llegar a convertirse en un mago más que en un yogui. No obstante, sea cual sea la utilización propuesta para tales poderes, nadie en este contexto niega que acompañan el proceso normal hacia la liberación y que constituyen, por ende, su verificación.

Por extravagantes que puedan parecer dichos poderes dentro de las perspectivas occidentales, corresponden perfectamente al menos en el plano de las creencias, a la lógica natural del sistema. El yoga pretende conducir al individuo al último plan cósmico y trascendente en el que consigue identificarse con el Brahma. Por consiguiente, precisa admitir para él (el yoga) la posibilidad de llevar a cabo algunas de las acciones de ese Brahma. Para el regreso al estado indiferenciado del Ser, para la identificación con el Ser absoluto, debe producirse un salto fuera de las categorías espacio-tiempo-causalidad.

Según Alexandra David-Neel, las gentes del Tíbet afirman que, por la concentración del pensamiento, los individuos ejercitados pueden proyectar las formas concebidas en el espíritu y de crear todo tipo de fantasmas: paisajes, objetos, animales, dioses y seres humanos ${ }^{54}$. Además, dicha investigadora pretendía haber llegado personalmente, después de varios meses de práctica, a crear un fantasma de lama que la seguia por todas partes, que fue visto por otras personas y que habiendo terminado por adquirir autonomia, se volvió cada vez más inoportuno ${ }^{55}$.

En cualquier caso, los relatos hindúes no han cesado de hablar de yoguis capaces, ya sea de obtener la inmortalidad $o$, cuando menos edades prodigiosamente prolongadas, ya de desdoblarse, de penetrar en el cuerpo

53. «Estos aforismos sobre el Yoga no constituyen la exposición original de una filosofía, sino un trabajo de compilación llevado a cabo dentro de un período que oscila entre el siglo IV y el I d. de C., por un sabio hindú llamado Patanjali, para que la doctrina Yoga expuesta siglos antes de los Upanishad, sirvieran de orientación y enseñanza a los hombres de su época". F. CLImENT, YogaSutras de Patanjali, Diana, México, 1974, p. 9.

54 Ver A. DAVID-NeEL, Misticos y Magos del Tibet, Espasa-Calpe, Madrid, 1968, pp. $221-232$.

55 Ibid., pp. 247-248. 
de otro individuo, e incluso de reanimar los cadáveres. Asimismo, numerosos son los fenómenos telepáticos, de visión a distancia y de profecía que, en general, se ha dicho que acompañan al yoga.

Patanjali se refiere, en su lista de los siddhi, a todos los "poderes" legendarios que obsesionan tanto al folclore como a la mitología y a la metafísica india. Al explicar por qué el samyama ${ }^{56}$ relativo a la forma del cuerpo puede hacer invisible al practicante, Patanjali señala que el samyama vuelve imperceptible el cuerpo al resto de los sujetos, y «como el poder de manifestación en el ojo está separado, se hace invisible el cuerpo del yogui» (Yoga-Sutras, III, 21).

Patanjali cita asimismo los otros "prodigios" que se consiguen por el samyama, tales como conocer con exactitud el instante de la muerte (Yoga-Sutras, III, 23), o poderes físicos extraordinarios (Yoga-Sutras, III, 25), o "el conocimiento de lo sutil, lo oculto, lo distante" (Yoga-Sutras, III, 26), etc. Todo lo que es "meditado", es —por la virtud mágica de la meditación - asimilado, poseído. Un yogui fue siempre considerado en la India como un mahasiddha, un detentador de poderes ocultos, un hechicero, un mago.

Según Patanjali, y la tradición del Yoga clásico, el yogui utiliza los incontables "poderes" con el objetivo de recuperar la libertad última, de ninguna manera para conseguir el dominio - fragmentario y provisorio- de los elementos. Porque es la liberación y no los "poderes ocultos" la que representa al verdadero «dominio».

El Buda también habla de los siddhi y la descripción que da de ellos sigue muy de cerca la tradición mágica panhindú así como la, inmemorial, de los chamanes y de los brujos "primitivos".

El monje (bhikku), recuerda el Buda:

"experimenta las variadas clases de poderes extraordinarios: Siendo uno, se torna múltiple, siendo múltiple, se torna uno; puede aparecer y desaparecer; sin encontrar resistencia va a través de las paredes, a través de las cercas, a través de las montañas, como en el aire; se hunde en la tierra o emerge de ella, como en el agua; camina sobre el agua sin que ésta se abra, como en la tierra; va a través del espacio en postura pallanka, como un pájaro alado; toca y palpa con su mano el sol y la luna, tan poderosos, tan maravillosos; hasta el mundo de Brahma ejerce su poder con su cuerpo" 5 ?.

56 Samyama designa las fases finales de la técnica yogui: la concentración (dharana), la meditación (dhyana) y la contemplación (samadhi).

57 C. Dragonetti (dir.), Digha Nikaya, Monte Avila, Buenos Aires, 1977, p.199. 
No obstante, para el Buda tanto como para Patanjali, los siddhi son poderes paranormales cuya posesión no podemos eludir. A lo largo de la práctica meditativa, el bhikku (monje), desemboca necesariamente en un nivel de experiencia donde la percepción extrasensorial y el resto de los «poderes maravillosos» le son dados. El Buda, Patanjali y otros, llaman la atención no solamente sobre el peligro de mostrar dichos poderes, sino también sobre el peligro que representa para el que los posee,

"por cuanto el yogui está arriesgado a sucumbir a la tentación de la magia y de contentarse con el gozo de esos "poderes maravillosos", en lugar de proseguir su trabajo espiritual y de obtener la liberación final» ${ }^{58}$.

Uno de los más importantes Upanishad, a saber el Yogatattva nos proporciona detalles precisos y numerosos sobre los "poderes mágicos" conseguidos por la práctica y la meditación. Una larga lista de siddhi, deja ver el medio mágico en donde este Upanishad fue elaborado; se menciona la facultad de oir y de hablar bien, la clarividencia, la posibilidad de volverse invisible, la de adoptar cualquier forma, la de transportarse en un instante a gran distancia y la facultad de transformar el hierro u otros metales en oro, untándolos con excrementos. Este último poder manifiesta la conexión que existe entre determinada forma del Yoga y la alquimia ${ }^{59}$.

La ascensión y el vuelo mágico ocupan un lugar de primer orden en las creencias populares y en las técnicas místicas de la India. En efecto, elevarse por el aire, volar como un pájaro, franquear inmensas distancias en lo que dura un relámpago, desaparecer, etc. son algunos de los prodigios que el hinduismo y el budismo confieren a los arhats ${ }^{60}$, a los reyes y a los magos. Existe un gran número de leyendas y cuentos populares sobre los reyes y los magos voladores.

Asvaghosha, uno de los más importantes autores budistas, narra en su célebre poema Budda-Karita ${ }^{61}$ que al visitar el Buda por primera vez tras la iluminación, su ciudad natal, hizo una exhibición en ella de algunos "poderes maravillosos" (siddhi). Para convencer a sus seguidores de la autenticidad de sus poderes espirituales y preparar su conversión, comenzó

58 M. Eliade, Mitos, sueños y misterios, Grupo Libro 88, Madrid, 1991, p. 92.

59 Ver M. ElIADE, Yoga, inmortalidad y libertad, Ed. cit.,pp. 131-133. Herreros y alquimistas, Alianza, Madrid, 1974, pp. 113-124.

${ }_{60}$ Individuos cuyas impurezas están extinguidas y cuyos deseos han sido satisfechos; que se han desprendido de su carga; han alcanzado el objetivo y liberada la mente al obtener el conocimiento perfecto.

61 Ver E.B. Cowell (dir.), Buddhist Mahayana Texts, The Buddha-Karita of Asvaghosha, Dover, New York, 1969, pp. 1-158. 
a ascender y dividió su cuerpo en trozos, que dejó caer al suelo para volverlos a componer después ante la mirada atónita de los allí reunidos ${ }^{62}$.

Este milagro se encuentra muy unido a la tradición de la magia hindú que se ha convertido en el prodigio-tipo del faquirismo. El famoso «milagro de la cuerda» de ilusionistas y faquires genera la ilusión de una cuerda que asciende hacia el cielo hasta una gran altura y por la cual el maestro ordena trepar a su aprendiz hasta que éste desaparece de la vista del público. El faquir lanza su daga hacia arriba y los fragmentos del joven se precipitan contra el suelo ${ }^{63}$.

Hay una gran cantidad de material en torno al «milagro de la cuerda» en la India antigua y moderna. Este espectáculo mágico también se ha encontrado en el antiguo México, Irlanda, Indias holandesas y China.

\subsection{Dioses ligadores y la magia de los nudos}

Los himnos védicos nos muestran la forma más antigua de la religión védica. Dyaus, el dios indoeuropeo del cielo, ya ha desaparecido del culto. Pero su lugar fue muy pronto ocupado por Varuna, el dios supremo por excelencia.

Varuna es un "dios ligador", y una gran cantidad de signos y rituales tienen como objetivo liberar o proteger al individuo de los «lazos de Varuna": "Rompe las cadenas que nos atan, por arriba, por abajo y en medio, a fin de que podamos vivir" 64 .

Varuna tiene el poder mágico de atar y de desatar a los seres humanos a distancia. Se le representa con una cuerda en la mano, y en las ceremonias y rituales todo cuanto une, comenzando por los nudos, se denomina «varuniano» 65 .

G. Dumézil justifica este prestigio mágico del señor ligador por la soberanía de Varuna:

"Las ligaduras de Varuna son tan mágicas como es mágica la soberanía en si misma; son el simbolo de estas fuerzas misticas detentadas por el jefe

62 Ver M. ElIADE, Mefistófeles y el andrógino, Guadarrama, Madrid, 1969, p. 205.

63 Véase M. EliADE, El chamanismo, Fondo de Cultura Económica, México, 1976, p. 333.

64 VYASA, Los Vedas, Ed.cit., p.77. A.M ${ }^{a}$ VÁZQUEZ, Diccionario de Símbolos y términos mágicos. Madrid, UNED, 1994, sv. "nudos"; id. J. DEL HoYo, "La Gorgona y su triple poder mágico", Espacio, Tiempo y Forma, Serie II, nº 3, Madrid 1990 pp. 117-182.

65 Ver M. EliADE, Historia de las creencias y de las ideas religiosas, De la Prehistoria a los misterios de Eleusis, Ed. cit., p. 216. 
y que se llama: justicia, administración, seguridad real y pública, todos los "poderes". Cetro y ligaduras, danda y pacah, en la India y en otras partes, tienen el privilegio de representar todo esto" ${ }^{66}$.

En la India védica no es sólo Varuna la única divinidad «ligadora»; existen tres más que son: Indra, Yama y Nirrti.

Indra, como Agni y Soma, libera a los individuos de los lazos de Varuna $y$ de las cadenas de los dioses funerarios; sin embargo, los lazos no constituyen en Indra una característica fundamental, incluso cuando el lazo deba considerarse como uno de sus instrumentos bélicos. No obstante, los nudos son los elementos constitutivos de Yama y Nirti, dioses de la muerte.

Las prácticas mágicas diferencian numerosas categorías de lazos y nudos y establecen una verdadera morfología.

"Se podrían clasificar los hechos más importantes bajo dos grandes epígrafes: $1^{\circ}$ los "lazos" mágicos utilizados contra los adversarios humanos (en la guerra, en la brujería), y la operación inversa de la "ruptura de los lazos"; $2^{\circ}$ los nudos y los lazos benéficos, medios de defensa contra los animales salvajes, contra las enfermedades y sortilegios, contra los demonios y la muerte" ${ }^{67}$.

En la primera modalidad se puede hablar de los lazos mágicos dirigidos contra los enemigos, la cuerda oculta en las proximidades de la casa de un adversario, o incluso escondida en su barca, para provocar su hundimiento.

En lo que respecta a la "cortadura de los lazos», aparece usada ya en el Atharva Veda; y en esta misma línea, como medio preventivo, se suele leer en los libros etnográficos que las personas deben procurar evitar los nudos sobre sus cuerpos en ciertas épocas clave: muerte, matrimonio, parto, etc.

En la segunda modalidad, se pueden clasificar todos los usos que atribuyen una función curativa a los lazos y a los nudos, así como de protección contra las entidades demoníacas, y de preservación de la fuerza mágico-vital.

En el ámbito de la magia, el ser humano utiliza nudos-amuletos para protegerse contra las ligaduras de los brujos y de las entidades demoníacas.

En el terreno religioso, se siente "ligado" por Dios; también la muerte le "liga", metafóricamente (los demonios «ligan» el alma del muerto), en concreto (el muerto se «ata»).

66 Citado en M. ElIADE, Imágenes y símbolos, Ed. cit, p.105.

67 Ibid., p. 117. 
Aún más, la propia vida es un «entramado" (en ocasiones un entramado mágico de alcance universal, maya), o existe un «hilo", que mantiene la vida de cada uno de los hombres.

Todos estos puntos de vista presentan algunos elementos comunes. En todas partes, la meta final del ser humano es soltarse las «ligaduras»: a la iniciación mística del laberinto -en el curso de la cual se aprende a deshacer el nudo laberíntico a fin de encontrarse en situación de desatarlos cuando el alma se lo encuentre tras la muerte - responde la iniciación filosófica, metafísica, cuya meta es destruir el velo de la ignorancia y liberar el alma de los lazos existenciales. En efecto, el pensamiento hindú se encuentra imbuido por este afán de liberación, y su terminología más característica puede reducirse a fórmulas binarias tales como «liberado-encadenado», "desligado-ligado", etc. ${ }^{68}$.

\section{II.6. Mantras, yantras, mandalas, mudras}

El ritual del hinduismo moderno ha cambiado mucho desde los tiempos védicos. El antiguo sacrificio del culto védico en forma de ceremonia larga con ofrenda al dios Agni del fuego y sacrificio de animales ya no se hace sino por ricos donantes, maharajas, muy raramente. Sólo sobreviven los antiguos cultos privados a los cuales se han unido muchas prácticas locales y especulaciones de los tantras, lo que ha cambiado mucho el orden y el simbolismo del ritual.

De los tiempos védicos se ha conservado el concepto de la potencia mágica del mantra ${ }^{69}$, de la fórmula sagrada que tiene un valor extraordinario en sí, aunque su significado sea oscuro. Su potencia reside en la manera de pronunciarlo, en la concentración mental que lo acompaña y en la iniciación que el recitador ha recibido de un maestro espiritual. Se recita a menudo el mantra, lo que constituye el jopa, "murmullo", cuyo valor crece según sea oral, susurrado o mental. Hay recitaciones de textos sagrados, de himnos a las divinidades que tienen los mismos beneficios, vinculados antiguamente a ritos védicos o mágicos.

El mantra empieza casi siempre por la sílaba $O M$ (A-U.M.), que es la fórmula más sagrada del hinduismo; simboliza al Ser, al Brahma, al concepto

68 Ibid., pp. 117-118.

69 Véase J. Blofelo, Mantras. Sagradas palabras de poder, Edaf, Madrid,1981. A. GovINDA, Fundamentos de la mistica tibetana, Eyras, Madrid, 1980. 
divino más elevado. El mantra se comp̃one de sílabas más o menos arbitrarias, los bija, "gérmenes», que simbolizan a la divinidad. El hindú suele tocar algunas partes de su cuerpo con los dedos, tales como la frente, la boca, el pecho, los brazos, la columna vertebral y pronunciar el bija para recibir la fuerza divina.

Se utiliza también el yantra o figura geométrica, diagrama, serie de círculos, de triángulos y de cuadrados que simbolizan el cuerpo de la deidad. Suele estar formado por un cuadrado con cuatro aberturas o "puertas", en sus lados; dentro de él están encerrados triángulos concéntricos unidos por radios. Los diseños que se usan para los yantras varían de unas a otras divinidades.

Otro conocido diagrama místico está formado por complicados triángulos equiláteros, cuadrados y círculos que representan las puertas de acceso a las deidades y sus mansiones.

Estos diagramas están inscritos sobre escabeles, sobre hojas de abedul en el caso de Rama, o sobre tablillas hechas de una aleación de cobre.

La palabra mandala procede del sánscrito y significa "círculo" sagrado o mágico; también "cerco".

Ante todo el mandala delinea la superficie consagrada y la protege de la invasión de las fuerzas disgregadoras simbolizadas en ciclos demoníacos. Es, sobre todo, un cosmograma,

"el universo entero en su esquema esencial, en su proceso de emanación y reabsorción: el universo no sólo en su inerte extensión espacial, sino como revolución temporal; y una y otra como proceso vital que se desarrolla por un principio esencial y rota alrededor de un eje central, la montaña Sumeru, el axis mundi sobre el que se apoya el cielo y que hunde las bases en el subsuelo misterioso" 70 .

Esta es una idea panasiática a la que contribuyeron a dar claridad y concreción las concepciones cosmográficas expuestas en el esquema de la ciudad imperial de los monarcas iranios y después en la imagen ideal del palacio del cakravartin, el rey universal de las leyendas indias. Dichas teorías y equivalencias cosmográficas de origen asirio-babilónico se adaptan, no obstante, a intuiciones primitivas según las cuales los magos o los

70 G. Tuccl, Teoría y práctica del mandala, Dédalo, Buenos Aires, 1975, p. 35; A.M ${ }^{a}$ VÁzQUEz: «La magia de la palabra", Espacio. Tiempo y Forma, serie II, 7, Madrid 1994, pp. 327-362. 
sacerdotes delinean sobre la tierra un espacio sagrado; ésta no sólo representa una defensa de las fuerzas arcanas que amenazan la superficie sacra del lugar o la integridad mental del que cumple el ritual, sino también, por transposición mágica, el mundo mismo; allí el oficiante se identifica, situándose en el centro, con las fuerzas que regulan el cosmos y recoge en si la potencia taumatúrgica ${ }^{71}$.

En la antigua India se usaba para este objetivo el vaso: se ponían cinco vasos en cinco zonas del mandala. El vaso quedó como elemento imprescindible de todo ritual hindú en que se cumpla la avahana, el descenso de la esencia divina al proyectarse e instalarse en un objeto o en una estatua. Dicho descenso se produce ante todo en el plano celeste y baja luego al vaso, pasando por la mediación del que oficia el sacrificio. El pequeño espacio del vaso o de la superficie delineada se volvía, de este modo, mágicamente el cosmos sobre el que actuaba el oficiante identificado con las fuerzas supremas, y según las leyes inviolables de la ceremonia.

Según H. von Glasenapp:

«Para que un mandala pueda desplegar plenamente las fuerzas que contiene, es preciso observar las siguientes reglas particulares: medir el emplazamiento donde se le dibujará, proceder con un tiempo astrológicamente favorable, etc. Antes de llevar a cabo las acciones sagradas, en el centro de las cuales se yergue un mandala, el sacerdote se transforma en un rey del saber, que caza a los demonios. Luego, invita a aquellos que son dignos de recibir tal honor a ocupar su sitio en el mandala; se identifica con ellos por medio de la meditación $y$, más tarde, los hace ingresar a su paraíso" 72 .

Por último, los hindúes utilizan un sistema de signos secretos de eficacia mágica que se hacen con las manos colocadas en determinadas posiciones, mudras, cada una dotada de una significación precisa; estos mudras se hacen también durante las danzas sagradas y pueden contemplarse en las estatuas.

Las plegarias védicas se acompañan siempre con gestos, por ejemplo, la plegaria de la mañana contiene veinticuatro mudras que simbolizan otros tantos aspectos de Vishnú.

En el tantrismo ${ }^{73}$ adquirió mucha importancia la utilización de gestos rituales; por razones poco claras, esta palabra sirve para designar a la mujer que participa en el rito sexual del tantra "de la mano izquierda».

71 Ibid., pp. 35-37.

72 H. von Glasenapp, Misterios budistas, Ediciones Esotéricas, Buenos Aires, 1974, p. 101.

73 Ver J. Rıvı̇̇RE, El yoga tántrico, Kier, Buenos Aires, 1978. 


\section{Según Mircea Eliade:}

"Otros mudra tienen por resultado la adquisición de siddhi bien conocidos: el poder de planear en el aire, el conocimiento del porvenir, y hasta la inmortalidad (mediante la vajrolimudra)" ${ }^{74}$.

\section{BIBLIOGRAFIA}

AA.VV. (1957): La India Antigua y su civilización, Uteha, México.

Asoka (1987): Edictos de la Ley Sagrada, trad. Rodríguez Adrados, R., Edhasa, Barcelona.

BLOFELD, J. (1981): Mantras. Sagradas palabras de poder, Edaf, Madrid.

CID, C. (1962): Mitología Oriental llustrada, Vergara, Barcelona.

Climent, F. (1974): Yoga-Sutras de Patanjali, Diana, México.

CowELL, E.B. (dir) (1969): Buddhist Mahayana Texts, The Buddha-Karita of Asvaghosha, Dover, New York.

DAVID-NeEL, A. (1968): Misticos y Magos del Tibet, Espasa-Calpe, Madrid.

DragonetTI, C. (dir.) (1977): Digha Nikaya, Monte Avila, Buenos Aires.

DUMÉzIL, G. (1970): Los díoses de los indoeuropeos, Seix Barral, Barcelona.

ELIADE, M. (1969), Mefistófeles y el andrógino, Guadarrama, Madrid.

- (1974), Herreros y alquimistas, Alianza, Madrid.

- (1976), El chamanismo, Fondo de Cultura Económica, México.

- (1978), Historia de las creencias y de las ideas religiosas. De la Prehistoria a los misterios de Eleusis, Cristiandad, Madrid, Vol. I.

- (1979), Imágenes y símbolos, Taurus, Madrid.

- (1981), Tratado de Historia de las Religiones, Cristiandad, Madrid.

- (1988): Yoga, inmortalidad y libertad, La Pléyade, Buenos Aires.

- (1991), Mitos, sueños y misterios, Grupo Libro 88, Madrid.

EMBREE, A.T. y WILHELM, F. (1974): Historia del subcontinente desde las culturas del indo hasta el comienzo del dominio inglés en Historia Universal, Siglo XXI, Madrid.

FELICE, P. DE (1975): Venenos sagrados. Embriaguez divina, Felmar Madrid.

GANDHI (1977): El Bhagavad-Guita de acuerdo a Gandhi, Kier, Buenos Aires.

GLASENAPP, H. VON (1974), Misterios budistas, Ediciones Esotéricas, Buenos Aires.

- (1977): La filosofia de los hindúes, Barral, Barcelona.

Govinda, A. (1980): Fundamentos de la mistica tibetana, Eyras, Madrid.

GUENON, R. (1969): Símbolos fundamentales de la ciencia sagrada, Eudeba, Buenos Aires.

GuiraRN, F. (dir.) (1965): Mitologia general, Labor, Barcelona.

HORNER, I.B. (dir.) (1991): Milinda's Questions, The Pali Texts Society, Oxford, Vol. II.

JAMES, E.O. (dir.) (1963): Historia de las religiones, Vergara, Barcelona, Vol. I.

- (1973): Introducción a la Historia Comparada de las Religiones, Cristiandad, Madrid.

LING,T. (1972): Las grandes religiones de Oriente y Occidente, Itsmo, Madrid, Vol. I.

MASSON-OURSEL, (1947): La filosofía en Oriente, Sudamericana, Buenos Aires.

MORA, J.M. DE (dir.) (1990): El Rig Veda Samhita, Edamex, México.

Mosterin, J. (1982): El pensamiento de la India, Salvat, Barcelona.

MourRe, M. (1972): Religiones y filosofía de Asia, Zeus, Barcelona.

ODIER, D. y SMEDT, M. DE (1972): Las místicas orientales, Martinez Roca, Barcelona.

RENOU, L. (1979): L'Hindouisme, PUF, París.

RIVIĖRE, J.R. (1960): El pensamiento filosófico de Asia, Gredos, Madrid.

- (1978): El yoga tántrico, Kier, Buenos Aires.

RoMÁN, Ma.T. (1994): “Buda: un personaje para la historia del antiguo oriente", ESPACIO, TIEMPO Y FORMA, UNED, Madrid. 
Sampurnanand (dir.) (1956): The Atharva Veda Vratyakanda, Ganesh and Co., Madras.

SCHUhMACHER, S. y WOERnER, G. (dir.) (1993): Diccionario de la sabiduría oriental, Paidós, Barcelona.

THAPAR, R. (1969): Historia de la India, Fondo de Cultura Económica, México, Vol. I.

TOLA, F. (1973): Doctrinas secretas de la India Upanishad, Barral, Barcelona.

Tucci, G. (1975): Teoria y práctica del mandala, Dédalo, Buenos Aires.

TULSIDAS (1981): El Ramayana, Visión Libros, Barcelona.

VÁzQUEZ, A.Mà. (1994): Diccionario de símbolos y términos mágicos, UNED, Programa de Enseñanza Abierta, Madrid.

- (1994), Id. "La magia de la palabra", Espacio, Tiempo y Forma, serie II, 7, Madrid, pp. $327-362$.

- (1990), DEL Hoyo, J.: “La Gorgona y su triple poder mágico", Espacio, Tiempo y Forma, serie II, 3, Madrid, pp. 117-182.

VILLAR, F. (1975): Himnos Védicos, Editora Nacional, Madrid.

VyASA (1974), Del Mahabharata, Diana, México.

- (1988): Los Vedas, Juan A. Bergua, Madrid.

ZIMMER, H. (1979): Filosofias de la India, Eudeba, Buenos Aires. 